\title{
Review article: Existing and potential evidence for Holocene grounding-line retreat and readvance in Antarctica
}

Joanne S Johnson $^{* 1}$, Ryan A Venturelli², Greg Balco ${ }^{3}$, Claire S Allen ${ }^{1}$, Scott Braddock ${ }^{4}$, Seth

Campbell ${ }^{4}$, Brent M Goehring ${ }^{2}$, Brenda L Hall ${ }^{4}$, Peter D Neff ${ }^{5}$, Keir A Nichols ${ }^{6}$, Dylan H Rood ${ }^{6}$,

5 Elizabeth R Thomas ${ }^{1}$, John Woodward ${ }^{7}$

${ }^{1}$ British Antarctic Survey, High Cross, Madingley Road, Cambridge, CB3 0ET, UK

${ }^{2}$ Department of Earth \& Environmental Sciences, Tulane University, New Orleans, LA 70118, USA

${ }^{3}$ Berkeley Geochronology Center, 2455 Ridge Road, Berkeley, CA 94709, USA

${ }^{4}$ School of Earth and Climate Sciences and the Climate Change Institute, University of Maine, Orono, ME 04469 USA

105 Department of Soil, Water, and Climate, University of Minnesota, Saint Paul, MN 55108, USA

${ }^{6}$ Department of Earth Science \& Engineering, Imperial College London, London SW7 2AZ, UK

${ }^{7}$ Department of Geography and Environmental Sciences, Northumbria University, Newcastle-upon-Tyne, NE1 8ST, UK.

15

Correspondence to: Joanne S Johnson (jsj@bas.ac.uk)

Abstract. Widespread existing geological records from above the modern ice-sheet surface and outboard of the current ice margin show that the Antarctic Ice Sheet (AIS) was much more extensive at the Last Glacial Maximum ( 20 ka) than at present. However, whether it was ever smaller than present during the last few millennia, and (if so) by how much, is known only for a few locations because direct evidence lies within or beneath the ice sheet, which is challenging to access. Here, we

20 describe how retreat and readvance (henceforth "readvance") of AIS grounding lines during the Holocene could be detected and quantified using subglacial bedrock, subglacial sediments, marine sediment cores, relative sea-level (RSL) records, radar data, and ice cores. Of these, only subglacial bedrock and subglacial sediments can provide direct evidence for readvance. Marine archives are of limited utility because readvance commonly covers evidence of earlier retreat. Nevertheless, stratigraphic transitions documenting change in environment may provide support for direct evidence from subglacial

25 records, as can the presence of transgressions in RSL records. With independent age control, past changes in ice structure and flow patterns revealed by radar can be used to infer ice volume changes commensurate with readvance. Since ice cores capture changes in surface mass balance, elevation, and changes in atmospheric and oceanic circulation that are known to drive grounding-line migration, they also have potential for identifying readvance. A multidisciplinary approach is likely to provide the strongest evidence for or against a smaller-than-present AIS in the Holocene.

Short Summary. Recent studies have suggested that some portions of the Antarctic Ice Sheet were less extensive than present in the last few thousand years. We discuss how past ice loss and regrowth during this time would leave its mark on geological and glaciological records and suggest ways in which future studies could detect such changes. Determining timing of ice loss and gain around Antarctica and conditions under which they occurred is critical for preparing for future climate warming-induced changes.

\section{Introduction}

Improving our understanding of the glacial history of the Antarctic Ice Sheet (AIS) during the Holocene (11.7 ka to present) is essential for determining the likely ice-sheet response to future ocean and atmospheric warming. The Holocene provides a wide range of climatic variation with which to examine interglacial ice-sheet behaviour under conditions similar to, or

40 warmer than, present (Hall, 2009). Holocene retreat and readvance of AIS grounding lines is theoretically predicted by relative sea-level reconstructions and suggested by some geological and glaciological observations. Here we consider how Holocene retreat and readvance could be detected and quantified using observations from geological and glaciological archives, illustrated in Fig. 1. Deglaciation from a much more extensive Last Glacial Maximum (LGM) ice-sheet 

of the present ice margin. However, whether or not the AIS grounding line was ever situated inboard of its present position during the Holocene, and (if so) by how much, is known only for a few locations. Evidence for a smaller-than-present ice sheet which then readvanced - a concept which we refer to hereafter as "readvance" - is difficult to find, as it lies underneath or within the relatively inaccessible modern ice sheet. Precise dating of both subglacial and englacial records is also challenging because dateable material is frequently lacking, and geomorphic context is hard to acquire. Although some

50 such evidence has been obtained (e.g., Venturelli et al., 2020), it is extremely limited, and interpretations are sometimes contradictory. For example, there is no agreed-upon explanation for the glaciological processes and environmental forcing leading to readvance (Kingslake et al., 2018; Neuhaus et al., 2021). Furthermore, the maximum extent of Holocene retreat has not yet been determined. In summary, the vastly greater weight of geological data from areas outside the present icesheet margin has led to a commonly accepted, but biased, paradigm that the AIS is now the smallest it has been since the

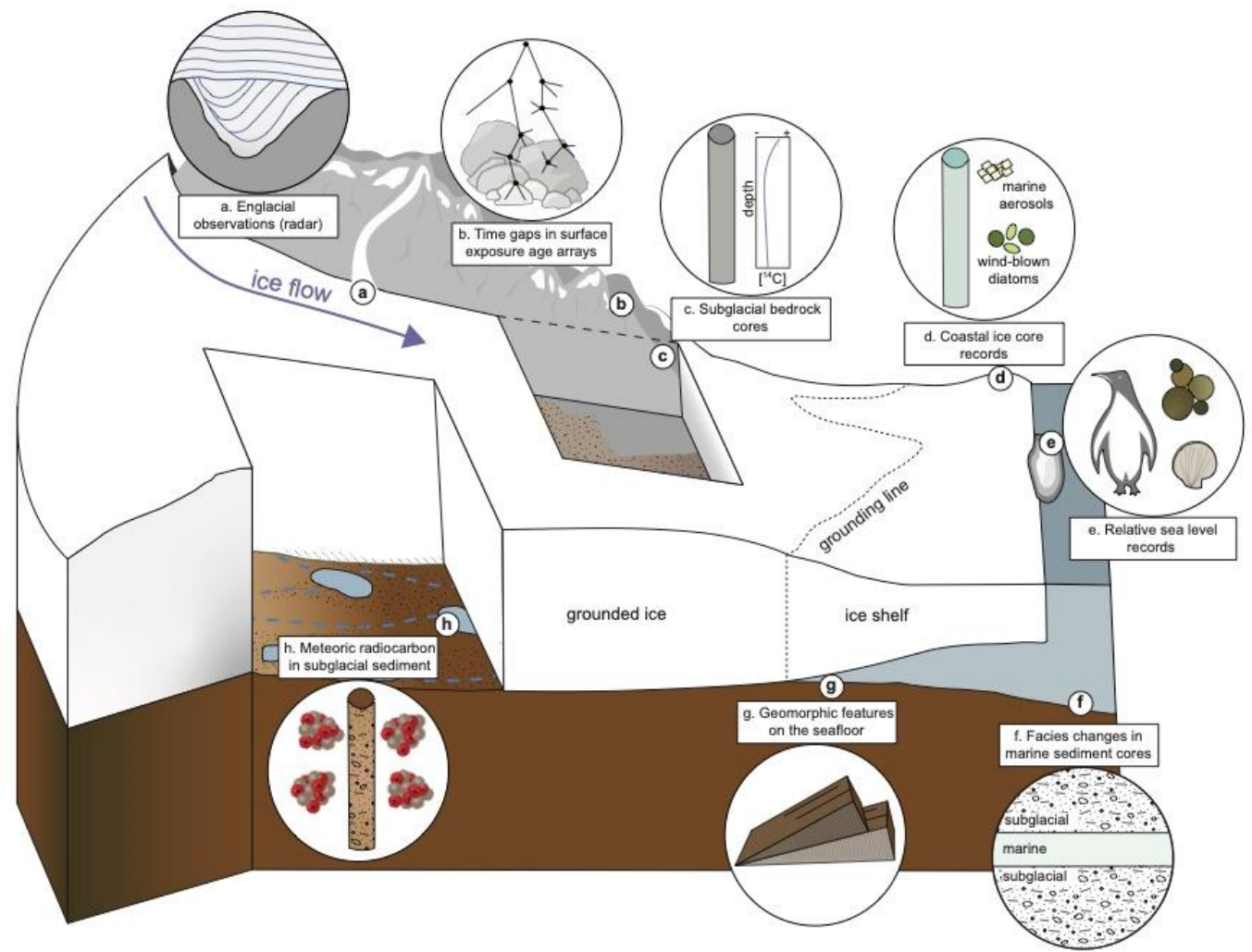

Figure 1: A recipe for reconstructing grounding-line retreat and readvance during the Holocene. This schematic illustrates geological and glaciological archives that may be used for paleoglaciological reconstructions. These are discussed in the paper as follows: englacial observations (Sect. 3.3.1), exposure age arrays (Sect. 3.1.1), subglacial bedrock cores (Sect. 3.2.2), ice cores (Sect. 3.3.2),

60 relative sea-level records (Sect. 3.1.3), marine sediment cores (Sect. 3.1.2), submarine geomorphic features (Sect. 3.1.2), subglacial sediments (Sect. 3.2.1).

Geological observations of readvance help ascertain the boundary conditions that enable expansion from a smaller-thanpresent configuration and provide data with which ice-sheet models can be validated and thereby improved (e.g., Golledge et

65 al., 2013; Lowry et al., 2019; Albrecht et al., 2020 a,b; Johnson et al., 2021). We outline the current evidence for Holocene readvance, describe the types of direct and circumstantial geological evidence that could theoretically be used to reconstruct 
its timing and magnitude, and suggest some approaches for future investigations. We also discuss the analytical and logistical challenges of obtaining different types of records.

\section{The principle of Holocene readvance behaviour}

70 In principle, Holocene readvance is expected to have occurred at least locally in Antarctica because of the interaction between global eustatic sea-level (ESL) change and glacio-isostatic rebound. More than $100 \mathrm{~m}$ of ESL rise between 19-7 ka, resulting from the disappearance of Northern Hemisphere ice sheets (Lambeck et al., 2014), may have forced Antarctic grounding-line retreat and consequent ice-sheet thinning (e.g., Clark et al., 2002; Gomez et al., 2020). This is recorded by numerous geological data indicating ice margin retreat across the Antarctic continental shelf and thinning at inland sites after

75 15-12 ka (RAISED consortium, 2014). By 6 ka, Northern Hemisphere ice sheets had fully disappeared, and ESL rise was essentially complete (Argus et al., 2014; Peltier et al., 2015). However, geological evidence indicates that post-LGM thinning of the AIS continued until at least this time in many locations, and beyond in some (refer to Fig. 2 and accompanying discussion in Sect. 3.1.1). Because the timescale for viscous relaxation is on the order of thousands of years, glacio-isostatic uplift of the underlying continent in response to this post-LGM thinning continued well after 6 ka. Thus,

80 most sites in Antarctica transitioned from experiencing relative sea-level (RSL) rise in the early Holocene to RSL fall in the mid Holocene (cf. figure 3, Whitehouse at al., 2012). As sea-level forcing of grounding-line positions is likely an important control on Antarctic ice extent (Gomez et al., 2010), it follows that the ice sheet should have reached its minimum configuration sometime in the mid to late Holocene and subsequently expanded to its current extent. Holocene readvance has been simulated by a few ice-sheet models in response to external forcing during the last glacial cycle (e.g., Kingslake et al.,

85 2018; Pollard and DeConto, 2012), but it is by no means ubiquitous in all models. Furthermore, those models are often poorly constrained by sparse geological observations and data-model mismatches are common (e.g., Johnson et al., 2021; Nichols, 2020; Spector et al., 2019; Jones et al., 2021), which decreases confidence in their ability to reliably simulate past ice-sheet change.

\section{Is it possible to detect Holocene retreat and readvance using glacial-geological evidence?}

90 Glacial-geological records of past ice-sheet fluctuations can be categorised as either direct or circumstantial. Direct evidence can provide conclusive proof of a particular configuration or hypothesis, whereas circumstantial evidence implies, or is not inconsistent with, a particular configuration, but is not direct proof of it. Multiple lines of direct and/or circumstantial evidence can strengthen conclusions about the timing and magnitude of ice-sheet retreat.

In the following sections, we describe a range of glacial and geological records that have the potential to provide direct or

95 circumstantial evidence for retreat of the Antarctic grounding line upstream of its present position during the past few millennia. These records are situated either below or within the modern ice sheet, or in currently exposed areas. A variety of approaches can be used to access these records, but there are considerable logistical challenges, as explained below.

\subsection{Evidence currently above or adjacent to ice}

\subsubsection{Evidence of a time gap in which readvance could have occurred}

100 At numerous locations around Antarctica, cosmic-ray exposure dating of glacially transported erratic cobbles and icescoured bedrock surfaces has provided Holocene constraints on the timing of deglaciation. Specifically, exposure age data from currently ice-free areas record past ice thickness changes upstream of the grounding line. Retreat of the grounding line would be accompanied by dynamic thinning upstream, assuming reasonable limits on surface mass balance changes. 
Therefore, evidence of rapid thinning at sites near and upstream of present grounding lines provides evidence for past

105 grounding-line retreat. The premise of exposure dating is that cosmic-ray interactions with rocks and minerals exposed at Earth's surface induce nuclear reactions that give rise to rare nuclides not produced by other natural processes. However, shielding of the surface by more than approximately $10 \mathrm{~m}$ of ice (or an equivalent mass thickness of anything else) stops nearly all of the cosmic-ray flux and prevents nuclide production. Erosion beneath ice sheets commonly generates fresh rock surfaces that have not been exposed to the cosmic-ray flux, so the concentration of cosmic-ray produced nuclides, expressed

110 as an "exposure age," in a rock surface uncovered by retreat records the time when that retreat exposed the surface (Dunai, 2010). Thus, exposure age records of LGM-to-present deglaciation comprise arrays of ages, measured in either bedrock or glacially transported clasts collected at a range of elevations from a single nunatak, in which exposure age systematically increases with elevation (e.g., Stone et al., 2003; Fig. 2). Exposure age data collected from above the modern ice surface cannot provide direct evidence that the ice at that site was ever thinner than present. However, they can prove that the ice

115 was not thinner at a particular time: for example, exposure ages of 4 ka above the present ice surface would exclude any scenario that called for thinner-than-present ice at $4 \mathrm{ka}$.

Many exposure age data sets from Antarctica can thus be used to determine whether or not Holocene readvance could have occurred in certain regions. As shown in Fig. 2, some exposure age arrays include multiple late Holocene ages from above

120 the present ice surface, and a thinning history inferred from these arrays intersects the modern ice surface at approximately the present time (see sites 26 and 27 in Fig. 2). Late Holocene thinning below present, and subsequent thickening, could not have occurred at these sites. On the other hand, many exposure age arrays intersect the present ice surface in the middle Holocene, typically in the range 2-6 ka, and do not include any younger exposure ages. At these sites, late Holocene readvance could have occurred. In fact, readvance would appear probable at these sites because the only alternative

125 explanation for these data is zero change in ice thickness during the late Holocene. Whilst possible, zero late Holocene change seems unlikely given that continued dynamic adjustment of ice thickness to RSL change was presumably occurring during this period.

A survey of existing exposure age data from Antarctica shows that occurrences of these two scenarios are not geographically

130 patterned (Fig. 2). Sites where exposure age data permit Holocene readvance are common in the Weddell and Amundsen Sea embayments. In contrast, datasets from the inner Ross Sea embayment uniformly preclude readvance, whilst datasets in the outer Ross Sea coast (northern Victoria Land; sites 20-25 in Fig. 2) permit it. For the East Antarctic coast, there are very few data and only one location (site 19 in Fig. 2, in the Lambert Glacier region) with an extensive enough data set to be unambiguously classified for this purpose. Although there are many sites elsewhere in East Antarctica where Holocene

135 exposure ages have been determined (white circles in Fig. 2), the majority of these sites have only one or two ages, or are located adjacent to sea level where readvance could not be detected. Overall, existing exposure age data are (i) consistent with the hypothesis that late Holocene readvance took place in the Weddell and Amundsen Sea embayments and at outer Ross Sea sites, (ii) not obviously consistent with the hypothesis that readvance took place in the inner Ross Sea, and (iii) provide minimal information for East Antarctica. 


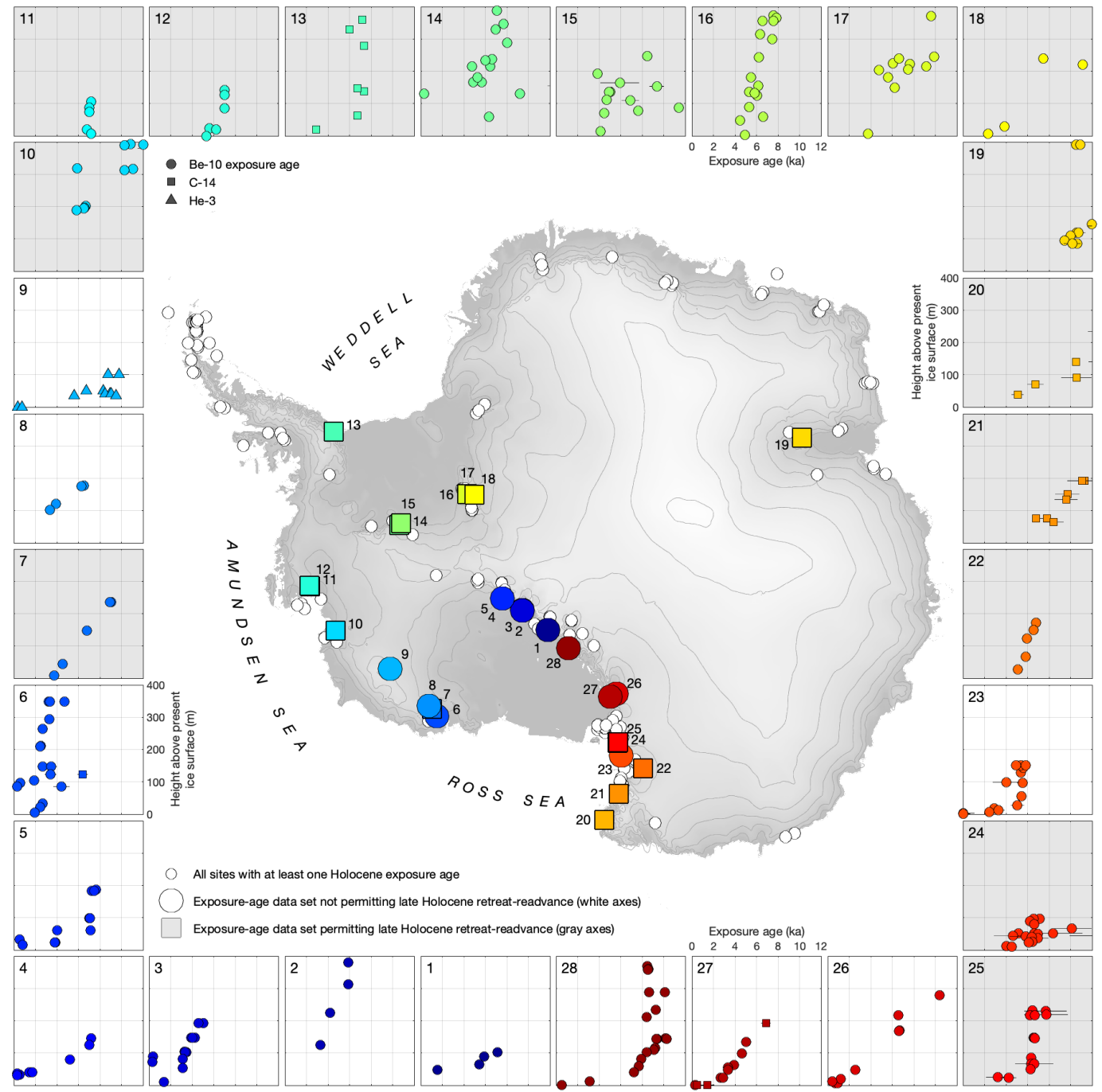

Figure 2: Evidence from Holocene exposure age data collected from various locations in Antarctica that do or do not permit ice surface lowering below the present elevation during the late Holocene. The figure was generated from the ICE-D:ANTARCTICA database (http://antarctica.ice-d.org). There are many sites (230) which have at least one Holocene exposure age (small white circles). This

145 figure shows only a subset of those sites or groups of sites that have more than four Holocene data which together display a reasonably coherent thinning history. Sites where the lowest data are at or near sea level are also excluded because thinning below sea level is unfeasible and could not be recorded by exposure age data anyway. The sites are classified by whether they do (squares, grey axes) or do not (circles, white axes) have a late Holocene gap where readvance could have occurred.

\subsubsection{Evidence for past grounding-line position from the marine record}

As an ice sheet advances across the continental shelf, it typically overrides and obliterates geomorphological evidence of prior retreat, such as grounding zone wedges or mega scale glacial lineations (e.g., Greenwood et al., 2021), and leaves depositional evidence of readvance, such as sedimentary transitions (e.g., Smith et al., 2019) and cross-cutting landforms (e.g., Greenwood et al., 2018). In a few locations, palaeo ice stream retreat and readvance did not entirely remove prior grounding zone deposition, but rather built composite grounding zone wedges that represent two separate periods of deposition [e.g., in the Ross Sea; (Greenwood et al., 2018); Weddell Sea; (Arndt et al., 2017)]. In most situations, however, 

depositional transitions in marine sediment cores that would be consistent with readvance. The clearest evidence would be a transition from a subglacial diamicton facies, overlain by diatom-bearing or diatomaceous mud (indicative of open-marine sedimentation), back to diamicton (Fig. 3a). At present, there are no published examples of such stratigraphic evidence indicating that this degree of change occurred during the Holocene. A form of evidence more likely to be found, yet not necessarily diagnostic, would be a stratigraphic transition from subglacial (diamicton) to ice proximal (stratified diamicton) or sub-ice-shelf facies (mud) back to subglacial (Fig. 3a). Reconstructions of past ice-shelf collapse [e.g., Ross Ice Shelf (Yokoyama et al., 2016); Prince Gustav Ice Shelf (Pudsey et al., 2001); George VI Ice Shelf (Bentley et al., 2005; Smith et

165 al., 2007); Larsen C Ice Shelf (Smith et al., 2021)] may also be useful for inferring changes in grounding-line position inboard of the collapse site. In summary, although these marine records alone cannot prove that Holocene readvance occurred, they can be used to support direct evidence provided by terrestrial archives.

(a)

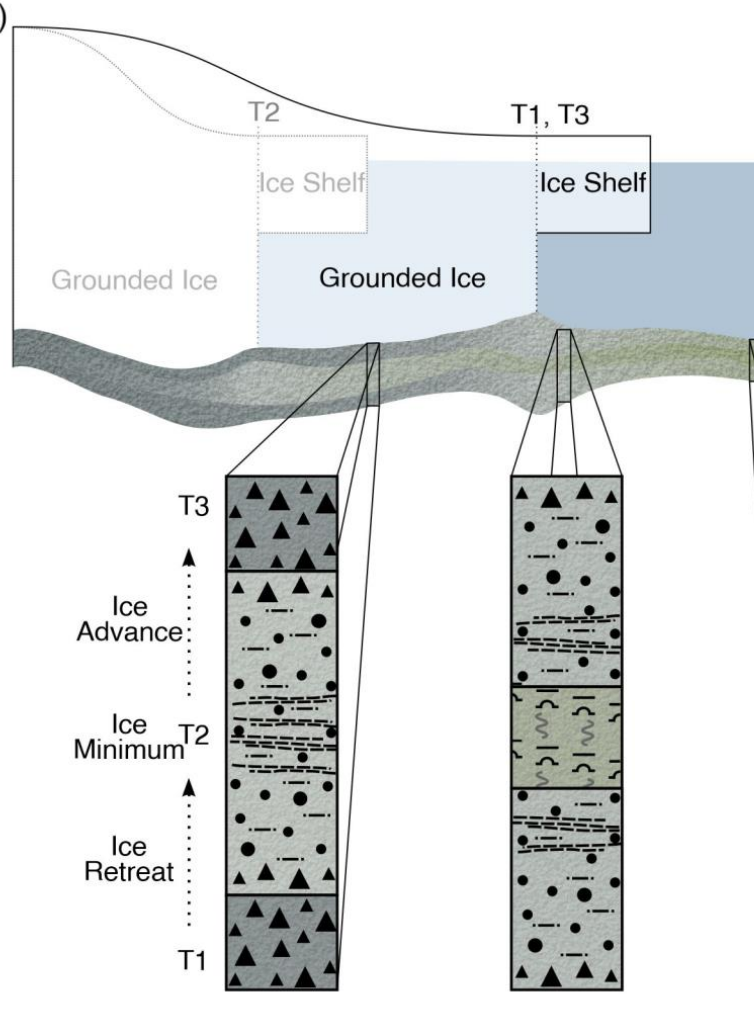

(b)

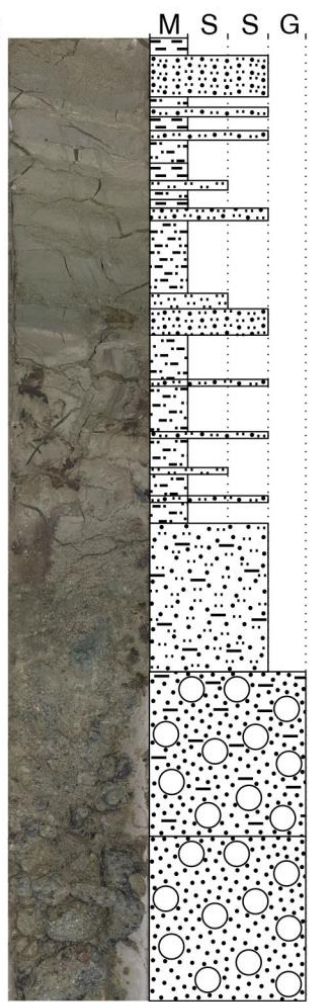

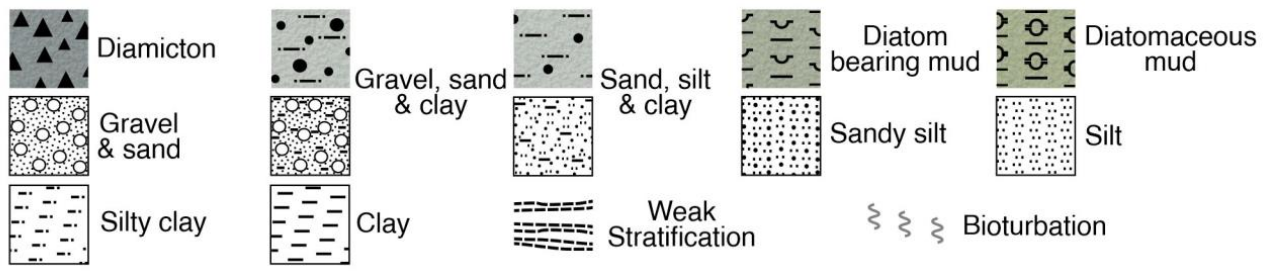

170

Figure 3: Facies changes in marine sediments that would be consistent with readvance. (a) Illustration of sediment logs recording an interval of reduced glacier extent (T2) between more advanced glacier positions (T1 and T3) for sub-glacial, glacio-proximal and glaciodistal settings; (b) Example of sediment transition from a sub-glacial/grounding-line-proximal to proglacial/sub-ice-shelf setting. 
175 3.1.3 Evidence for transgressions in relative sea-level records

Holocene readvance would theoretically result in ice mass changes detectable in sea-level records. Slowing rates of change or even transgressions in RSL records proximal to glaciated areas are commonly interpreted as ice mass gain where significant eustatic sea-level rise is absent (e.g., Motyka, 2003; Mann and Streveler, 2008; Simms et al., 2012; Farquharson et al., 2018). RSL records from around the AIS could afford evidence of glacial readvance if the expansion were of a

180 magnitude sufficient to cause measurable crustal depression, or at least a noticeable slowing of rebound rates. Antarctic RSL records have been reconstructed by dating beach deposits that were elevated above sea level by rebound using a variety of methods. These include radiocarbon dating of organic material (e.g., shells, bones, seal fur) buried in beach ridges (e.g., Hall and Denton, 1999; Baroni and Hall, 2004), optically stimulated luminescence (OSL) dating of beach cobbles (e.g., Simms et al., 2012), and radiocarbon dating the marine-lacustrine transitions in isolation basins (e.g., Verleyen et al., 2005; Watcham
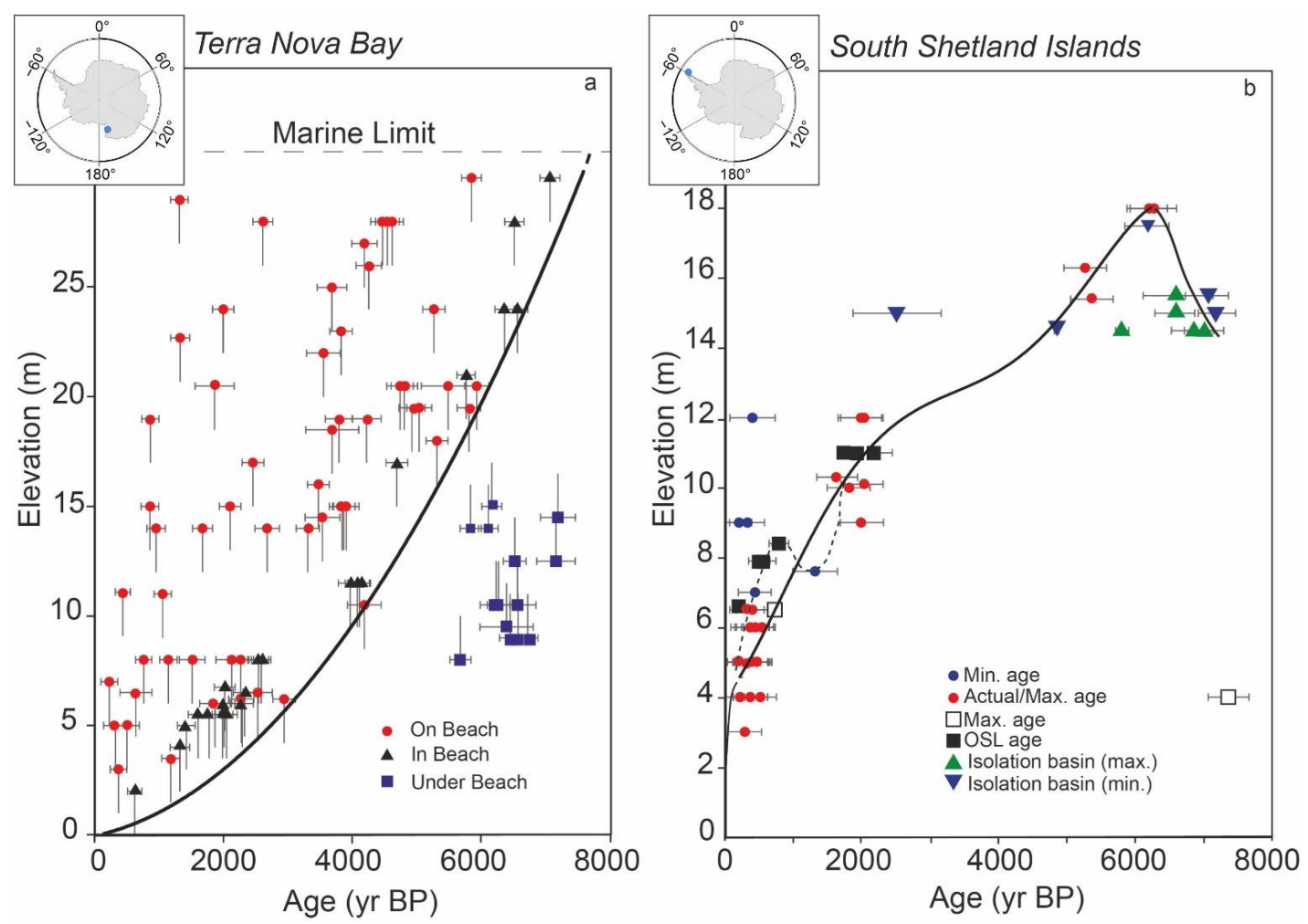

Figure 4: Two patterns of RSL change in Antarctica. (a) Many curves show a typical exponential shape, as represented by the curve

190 from Terra Nova Bay, Ross Sea region [Baroni and Hall (2004), recalculated with marine reservoir correction of Hall et al. (2010), updated for Marine20 calibration dataset)]. (b) A more complex pattern as represented by the South Shetland Islands. This curve is thought to show evidence of at least one ( $\sim 6.5-7 \mathrm{ka})$ and possibly two (dashed line) transgressions, linked to glacier advance (e.g., Hall, 2010; Watcham et al., 2011; Simms et al., 2012). Redrawn from curves of Hall (2010), Simms et al. (2011), and Watcham et al. (2011), with ages recalculated with Marine20. Circles denote radiocarbon samples from raised beaches (Hall, 2010 and references therein), squares are OSL dates of beach cobbles (Simms et al., 2011), and triangles are dates of the marine-freshwater transitions in isolation basins (Mäusbacher et al., 1989; Martinez-Macchiavello et al., 1996; Watcham et al., 2011). 
Concerted effort over the past two decades from several regions of Antarctica (e.g., Baroni and Hall, 2004; Roberts et al., 2011; Simkins et al., 2013; Verleyen et al., 2017) has resulted in a more complete understanding of Holocene Antarctic RSL

200 change. Most existing Antarctic records show simple RSL fall from 8 ka to present (e.g., Zwartz et al., 1998; Baroni and Hall, 2004; Bentley et al., 2005; Braddock et al., in review) and thus lack evidence for subsidence related to significant late Holocene ice growth. A notable exception in the South Shetland Islands (Fig. 4) provides evidence of one or more transgressions linked to ice expansions, most recently in the late Holocene (John and Sugden, 1971; Hall, 2010; Watcham et al., 2011; Simms et al., 2012). These transgressions are expressed in the records as changes in rate (and direction) of RSL change.

The occurrence of raised beaches proximal to extant ice masses can afford further evidence of Holocene readvance. Numerous locations [e.g., Ross Sea (Baroni and Orombelli, 1991; Hall and Denton, 2002; Baroni and Hall, 2004); South Shetland Islands (John and Sugden, 1971; Hall, 2010); Antarctic Peninsula (Simms et al., 2021)] show flights of raised

210 beaches that extend up to, and presumably beneath, present-day glaciers. These observations imply an extended period of reduced ice extent in the Holocene, permitting beach formation, subsequently followed by a late Holocene readvance. Further exploration and dating of such beach deposits could support the hypothesis of late Holocene readvance.

\subsection{Evidence currently under ice}

\section{3.2.1 Subglacial sediments}

Where the AIS is grounded below sea level, the grounding line serves not only as the boundary between the ice sheet and ice shelf, but also separates the isolated subglacial environment from the atmospherically connected marine environment. Radiocarbon $\left({ }^{14} \mathrm{C}\right)$ is produced in Earth's atmosphere and oxidised to ${ }^{14} \mathrm{C}$-bearing carbon dioxide $\left({ }^{14} \mathrm{CO}_{2}\right)$, which can enter the ocean system via photosynthesis (organic pathways) or air-sea exchange (inorganic pathways). The Antarctic subglacial environment, in contrast to the surrounding marine environment, is separated from the atmosphere by hundreds-to-thousands of metres of ice, cutting its microbial biosphere off from incorporating ${ }^{14} \mathrm{CO}_{2}$. Grounding-line retreat enables an incursion of ocean waters over subglacial sediments, leaving behind ${ }^{14} \mathrm{C}$ as a marker of the timing and extent of grounding-line retreat. The discovery of ${ }^{14} \mathrm{C}$ in bulk organic matter from the subglacial environment paired with an ice-sheet model was used by Kingslake et al. (2018) to imply that grounding-line retreat and readvance occurred in the Ross Sea embayment during the

225 Holocene. However, ${ }^{14} \mathrm{C}$ in bulk organic matter, which is not diagnostically linked to a single source in the way that a fossil would be, is ambiguous. This is because subglacial sediment contains both ${ }^{14} \mathrm{C}$-bearing organic carbon and glacially eroded fossil carbon (e.g., Sackett, 1986; Andrews et al., 1999). As such, preparatory techniques capable of separating ${ }^{14} \mathrm{C}$ from the remaining fossil (>50,000 year old) carbon are needed to unambiguously use ${ }^{14} \mathrm{C}$ in sub-ice sediments to provide chronological constraints on Holocene readvance. Venturelli et al. (2020) demonstrated that the Ramped PyrOx method

230 (Rosenheim et al., 2008) was sufficient for thermal separation of sub-ice organic matter, enabling the use of ${ }^{14} \mathrm{C}$ to determine the precise timing of the last marine incursion. Further work using subglacial sediments is thus likely to provide a geological constraint on the magnitude of grounding retreat prior to Holocene readvance (Venturelli, 2021).

\subsubsection{Subglacial bedrock}

Exposure age data from below the ice sheet could prove the hypothesis that the AIS was smaller in the Holocene than today:

235 if the ice sheet was thinner in the past, rock surfaces would exist that are now covered by enough ice to completely block the cosmic-ray flux, but were exposed to the cosmic-ray flux when the ice was thinner. A significant concentration of a cosmicray produced nuclide in a rock sample collected from beneath the ice sheet would be direct, unambiguous evidence that the ice sheet was thinner in the past. It would not strictly require surface exposure of bedrock, because the cosmic-ray flux can 
penetrate some thickness of ice, but it would require that the surface be covered by no more than about $10 \mathrm{~m}$ of ice or snow

for hundreds to thousands of years. A similar argument applies for luminescence-based tools [e.g., OSL and infrared stimulated luminescence (IRSL)] that involve measuring the amount of trapped charge in minerals accumulated when exposed to naturally occurring environmental radiation. Exposure to sunlight ("bleaching") releases trapped charge, and charge builds up slowly after exposure ends, so the method can detect recent exposure of mineral grains to sunlight (Aitken, 1998). OSL or IRSL evidence of bleaching in subglacial bedrock would require exposure of the rock surface to sunlight

245 either directly or through a very thin $(<1 \mathrm{~m})$ layer of clean ice or snow.

Thus, the basic concept of subglacial bedrock exposure dating via either cosmogenic-nuclide or luminescence measurements is quite simple: cosmogenic-nuclide concentrations above background levels or a bleaching signal in subglacial bedrock require thinner ice in the past. However, there are several challenges to implementing it. Firstly, accessing the bedrock below

250 the ice surface requires drilling a hole through the ice and into the underlying bedrock. A few past ice drilling projects recovered subglacial rock or sediment as a byproduct of ice core drilling, for example, at GISP2 in 1992 (Gow and Meese, 1996) and Taylor Dome in 1993 (Steig et al., 2000). In recent years several drill systems have been developed for the specific purpose of subglacial bedrock recovery that are lighter, more mobile, and more effective at collecting rock core than ice core drills (Kuhl et al., 2021; Boeckmann et al., 2021; Goodge and Severinghaus, 2016). These drills have now

255 successfully collected bedrock cores at several locations in Antarctica, including the Ohio Range in the Transantarctic Mountains (Boeckmann et al., 2021), Mt. Murphy at the Amundsen Sea coast (Boeckmann et al., 2021; Fig. 5), and the Pirrit Hills in central West Antarctica (Kuhl et al., 2021). Although the relatively small diameter (typically $2-5 \mathrm{~cm}$ ) of rock cores that can be collected by drilling imposes limits on sample size, subglacial bedrock recovery and exposure dating in frozenbed conditions characteristic of polar ice sheets is now routinely feasible.
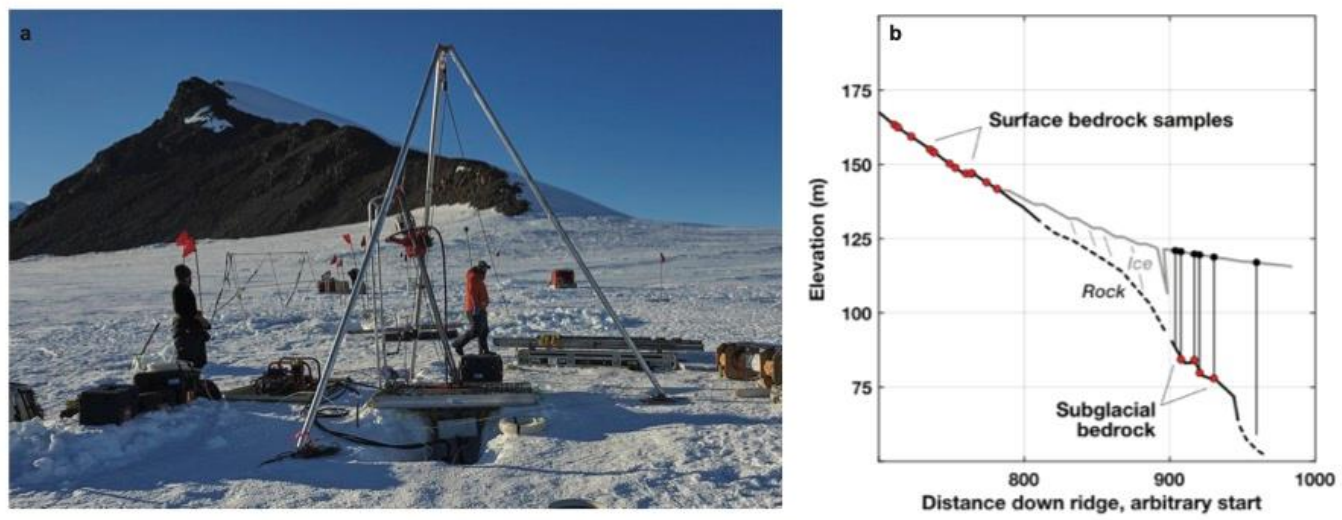

Figure 5: An example of subglacial bedrock drilling in Antarctica. (a) Photograph showing an attempt to collect subglacial bedrock samples for OSL and cosmogenic ${ }^{14} \mathrm{C}$ measurements to determine whether a late Holocene thinning-thickening cycle took place at Mt Murphy, between the Thwaites and Pope Glaciers in West Antarctica. (b) Plot showing profile along the ridge at Mt Murphy. Red circles

265 denote position of surface and subglacial bedrock samples. The lowermost bedrock samples on the exposed ridge above the present ice surface have exposure ages of $4 \mathrm{ka}$ (Johnson et al., 2020), leaving a late Holocene time gap during which the ice at this location could have been thinner. Drilling to collect subglacial bedrock samples took place in the 2019-20 Antarctic field season.

A second challenge lies in interpreting the cosmogenic-nuclide or luminescence measurements. Although detecting

270 subglacial exposure would always be unambiguous evidence of thinner ice in the past, not detecting subglacial exposure in a subglacial bedrock sample could mean either that the ice was never thinner, or that the ice was thinner in the past and the previously exposed surface was subsequently removed by erosion. For OSL and IRSL, regrowth of trapped charge following 


\author{
.
}

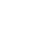

burial of a previously bleached surface will gradually remove evidence of surface exposure even without erosion of the surface, typically on a timescale of hundreds of thousands of years. Radioactive decay would have a similar effect for

275 relatively short-lived cosmogenic nuclides, but, since other simultaneously produced nuclides are longer-lived or stable, decay could not remove all evidence of cosmic-ray exposure acquired before the Holocene. Subglacial erosion, on the other hand, could remove both types of evidence, but can often be excluded by glaciological observations and/or modeling that explore whether or not a site could have hosted ice above the freezing point and be capable of enabling significant erosion.

280 Finally, although the presence of bleaching of an OSL signal or significant cosmogenic-nuclide concentrations in subglacial bedrock are clear evidence that ice was thinner in the past, it is not always possible to determine the timing of that thinning event. For OSL data, bleaching events that are relatively recent compared to the time required for regrowth of trapped charge can typically be unambiguously dated. For cosmogenic-nuclide data, if independent evidence indicates that the sample experienced only a single period of exposure and a single period of burial, the durations of both can be uniquely inferred

285 from measurements of two nuclides with different half-lives ("burial dating"; see Dunai, 2010). On the other hand, in the general case where (i) neither subaerial nor subglacial erosion was significant, (ii) bedrock surfaces experienced repeated periods of exposure and ice cover during glacial-interglacial cycles, and (iii) independent evidence for the number of exposure events is lacking, multiple-nuclide data typically limit the range of possible exposure-burial scenarios without implying a unique solution. In this paper, however, we are focusing on the very specific case of late Holocene thinning and

290 thickening at sites that are known to have been covered by ice between some time prior to the LGM and the mid to late Holocene. Identifying late Holocene exposure in this situation is relatively simple with measurements of $\operatorname{cosmogenic}{ }^{14} \mathrm{C}$, which is produced in quartz by cosmic-ray interactions and has a half-life of 5730 years. Thus, ${ }^{14} \mathrm{C}$ produced in any hypothetical surface exposure prior to the LGM would now be effectively undetectable due to radioactive decay. Although longer-lived nuclides, such as ${ }^{10} \mathrm{Be}$ (which has a half-life of $1.39 \mathrm{Myr}$ ), detected in subglacial bedrock could have been

295 produced either in the late Holocene or during many previous Pleistocene interglaciations, ${ }^{14} \mathrm{C}$ could only have been produced in the late Holocene. Significant ${ }^{14} \mathrm{C}$ concentrations above background would therefore be unambiguous evidence for late Holocene thinning. Thus, strategies for detecting late Holocene retreat and readvance via subglacial bedrock recovery drilling focus on OSL and cosmogenic ${ }^{14} \mathrm{C}$ measurements.

\title{
3.3 Evidence within ice
}

\section{3.3.1 Changes in ice structure observed with radar}

Ground-penetrating radar and radio echo sounding data (collectively referred to as "radar") acquired during the past four decades in Antarctica provide a vast record of glacier structure and past ice-sheet change reaching back decades to hundreds of thousands of years (e.g., Ashmore et al., 2020; Schroeder et al., 2019; Kehrl et al., 2018; Winter et al., 2019). Radar can reveal evidence of fluctuations in ice thickness and flow patterns with high spatial resolution (e.g., Campbell et al., 2013;

305 Conway et al., 1999; Siegert et al., 2013), making it particularly useful for determining regions across the AIS that experienced ice volume changes. The technique therefore has the potential to provide indirect evidence for readvance. In addition, it is feasible to collect tens to hundreds of kilometres of radar data in a single field season and potentially provide records of ice volume changes over larger spatial extents than other geological or glaciological techniques.

310 Stratigraphic unconformities within an ice sheet may form as a result of internal processes due to changes in ice behaviour or external drivers caused by changes in the ocean (e.g., Holland et al., 2020), atmosphere (e.g., Scambos et al., 2000), and solid earth dynamics (e.g., Larour et al., 2019). This could include, for example, retreat and subsequent readvance of the grounding line driven by warm ocean water, or spatial and temporal changes in atmospheric deposition. However, although radar stratigraphy may identify the spatial extent of past changes in ice volume, determining the timing of such events is 
315 challenging. Nevertheless, constraining a relative age of past readvance events can be achieved by comparing results from observations of stratigraphy in radar datasets with other methods such as exposure age dating, ice cores (Winter et al., 2016, 2019; Bodart et al., 2021), and climate or ice-history models. For example, Winter et al. (2019) matched distinct horizons to dated ice cores to place absolute ages on englacial stratigraphy. Absolute ages on distinct horizons observed in radar profiles provide further constraints on the timing of observed unconformities in local radar profiles, such as changes in the blue ice

320 area of Patriot Hills, West Antarctica (Winter et al., 2016; Fig. 6). Modelling of wind patterns and location of blue ice areas may in turn allow interpretations of the radar data to reveal changes in ice-sheet elevation (Mills et al., 2019).

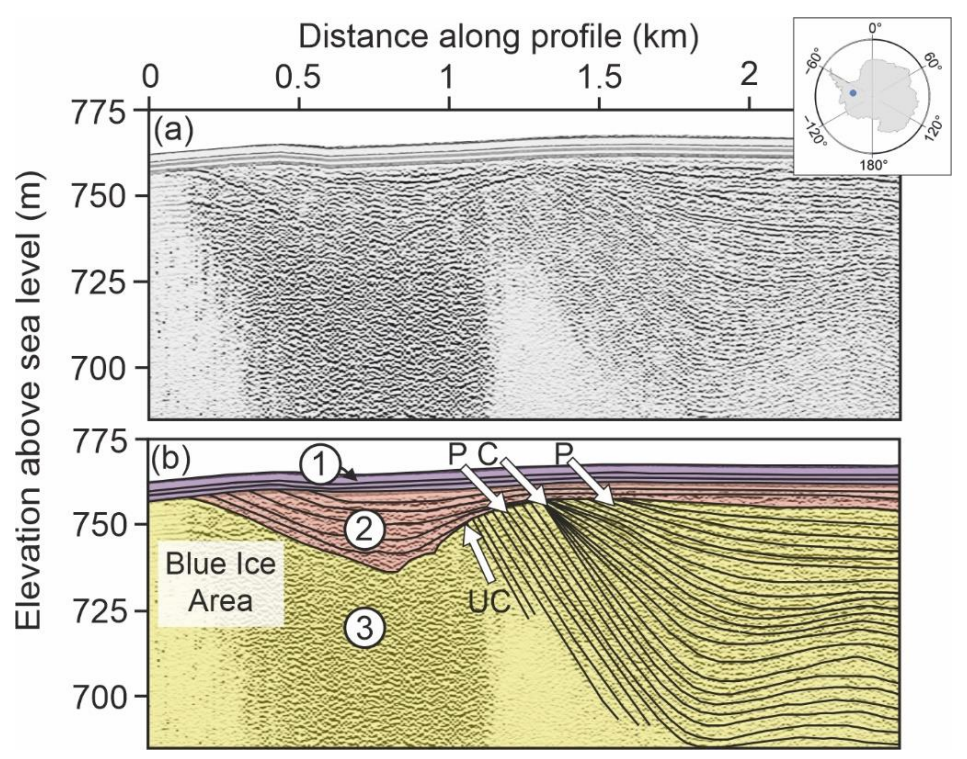

325 Figure 6: Ground-penetrating radar (GPR) showing an example of changes in internal isochrones within the ice sheet that formed as a result of changes in accumulation, ablation and ice flow around nunataks. (a) An elevation-corrected snowmobile-towed 200 MHz ground-penetrating radar profile from the margins of the blue ice area adjacent to Patriot Hills, Horseshoe Valley, West Antarctica (see map inset for general location; the data are also shown in figure 3 of Winter et al., 2016). (b) The same radar profile with coloured overlays, numbered 1-3, to show (1: purple) no structure is visible since the GPR direct wave hides the top $1 \mathrm{~m}$ of isochrones, (2: orange)

330 recent snow accumulation at edge of blue ice area, and (3: yellow) buried blue ice to the left of the image, with accumulation of snow over the blue ice to the right. Black lines highlight prominent internal reflectors within the snow accumulation layers. Prograding $(\mathrm{P})$ and convergent (C) isochrone sequences are indicated with arrows. "UC" indicates a stratigraphic unconformity where shallowly-dipping internal reflectors are overlain by near-horizontal firn; this represents the former blue ice surface, where ablation has removed the glacier ice. Following ablation, snow has been deposited on top of the exposed blue ice area as the ice unit flowed down valley away from the

335 present exposed blue ice ablation area. The image highlights the complexity of interpreting radar data in marginal areas, but also demonstrates that radar can hold a temporal record of changes in ice sheet elevation, flow patterns, accumulation and ablation.

Simple englacial stratigraphy is common in regions with slow-moving ice such as the centre of ice sheets or at ice divides. In contrast, complex englacial stratigraphy can occur in regions of fast flowing ice as a result of enhanced ice velocity leading

340 to unconformable internal ice stratigraphy, and by processes which represent a change in ice-sheet volume (e.g., Siegert et al., 2013; Bingham et al., 2015), as would occur during readvance. The degree of continuity of surface conformable layers provides a qualitative, and in some cases a quantitative, measure of previous deformation or alteration. For example, Siegert et al. (2013) used radar from the Weddell Sea sector of Antarctica to show that slow-flowing ice resting on top of a topographic high experienced a period of fast-flowing ice velocities sometime between 0.4 and 4 ka.

Radar can uncover the timing and spatial extent of ice mass changes by providing a link between independent methods, such as cosmogenic dating and ice core sampling. Past studies have used radar successfully to target drilling sites for ice cores (e.g., Campbell et al., 2013) and more recently, subglacial rock cores collected at Pirrit Hills and Ohio Range (Spector et al., 

subglacial bedrock sites for sampling efforts, these same techniques can be used concurrently to select ice core drilling locations at points of interest (e.g., previous surface or volcanic ash layers identified in radar profiles) and to provide independent ages for these observations. The simplest scenarios are perhaps at ice divides where asymmetrical Raymond arches may suggest down-glacier dynamical changes in which radar stratigraphy can provide direct evidence of glacier change during Holocene readvance (e.g., Raymond, 1983; Nereson et al., 2000; Vaughan et al., 1999; Conway et al., 1999).

355 There are other scenarios that could result in unconformities within radar profiles. For example, significant thinning followed by readvance and ice thickening might produce an unconformity visible within radar stratigraphy. This event would be observed as surface conformable stratigraphy overlaying buckled or disturbed stratigraphy, or it may include older ice that is topographically confined, under readvanced ice (see archive "a" in Fig. 1).

360 In summary, radar has (thus far) been under-utilised for obtaining indirect evidence of readvance. It can be used both for detecting ice-sheet changes associated with readvance and, when radar is coupled with methods that provide independent age constraints (such as ice cores and exposure age dating of bedrock), the timing of readvance. The lateral margins of West Antarctica are particularly suitable for radar studies that seek to detect readvance because ice-volume changes resulting in grounding-line retreat and ice-sheet thinning there are likely to be revealed in radar profiles from sites where temporal

365 constraints from ice core and exposure dating studies can also be obtained.

\subsubsection{Ice cores}

The geochemical composition of ice, together with the gas trapped in the bubbles within it, has the potential to capture changes in ice-sheet surface mass balance, elevation, and atmospheric and oceanic circulation (such as wind strength and sea surface temperature) that are known both to drive ice-sheet retreat and readvance, and be influenced by it. Ice cores therefore

370 provide an alternative source of information about grounding line behaviour, but, as yet, they have not been utilised for studies of Holocene readvance.

There are several potential approaches for extracting this information from ice cores. A well-established method for reconstructing past surface temperatures uses the relationship between stable water isotopes and temperature (e.g. Jouzel et

375 al., 1997). A number of mechanisms, including changes in ice-sheet elevation during ice-sheet readvance (or retreat), will alter this isotope-temperature relationship. The offset between ice core-derived temperature changes and estimates from isotope-enabled general circulation models can be largely reconciled when changes in ice-sheet elevation are taken into account (Werner et al., 2018; Buizert et al., 2021). Therefore, it may be possible to detect evidence that would be consistent with Holocene readvance from the isotope-temperature relationship within ice cores. Another promising approach for

380 reconstructing changes in elevation arises from the total air content in ice cores. The volume of air encapsulated in bubbles as they become isolated is dependent on air pressure and temperature when the bubbles are formed (Martinerie et al., 1992). Hence, the total air content extracted from ice cores is sensitive to changes in ice-sheet elevation. Total air content has been used to reconstruct the LGM elevation anomaly relative to the present, indicating a $420 \mathrm{~m}$ offset between East and West Antarctica (Buizert et al., 2021). When used in conjunction with stable water isotopes, the derived elevation changes since

385 the LGM indicate a thickening in West Antarctica (+300 $\mathrm{m}$ at WAIS divide; Fig. 7) and thinning in East Antarctica (-120 m at Dome C; Fig. 7). Despite the promise of this approach, resolution and detection may limit its use, with some studies suggesting that elevation changes of less than 150-250 m will be below detection (Martinerie et al., 1992).

Since mass balance of the AIS is dependent on both mass gain (from snow accumulation) and mass loss (melt, sublimation, calving), surface mass balance (SMB) may also reflect changes in ice-sheet volume and elevation changes (Davis et al., 

Holocene have been linked to the Little Ice Age (Bertler et al., 2011; Simms et al., 2021). Currently, only seven ice cores five from East Antarctica and two from West Antarctica, all from the ice-sheet interior - capture changes in snow accumulation for the full Holocene (Buizert et al., 2021). The large-scale pattern of SMB decline during the late Holocene is observed at all those sites, with the largest decline in West Antarctica starting at 2.5 ka (Fudge et al., 2016).

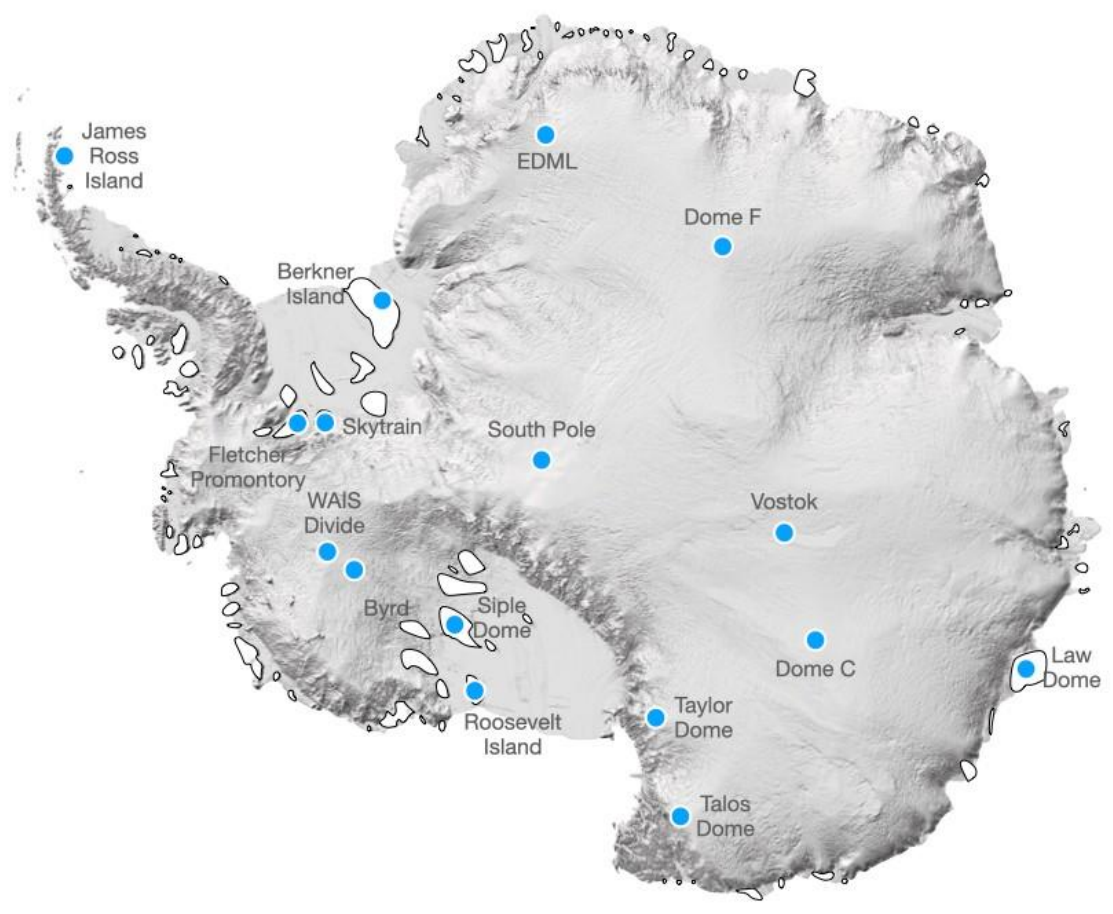

Figure 7: Map of Antarctica showing location of existing and potential ice core sites from which Holocene ice has been, or could be, obtained. Deep ice core sites from where Holocene ice has already been collected are represented by blue dots, and suitable locations for future sampling of Holocene ice near grounding zones - ice rises and ridges - are highlighted as white areas (locations from Matsuoka et al., 2015). The Reference Elevation Model of Antarctica hillshade base is from Howat et al. (2019).

Topographic changes associated with ice-sheet retreat and readvance alter the atmospheric circulation around, and over, the ice sheet. This can influence the direction or pathways of air masses reaching an ice core site. Changes in atmospheric circulation can be detected in ice core stable water isotope (e.g., Stenni et al., 2017) and snow accumulation records (e.g.,

405 Thomas et al., 2015, 2017; Medley and Thomas, 2019). They also impact the deposition in ice of chemical species such as sea salts (e.g., Dixon et al., 2004) and insoluble particulate matter such as dust and diatoms (Koffman et al., 2014; Allen et al., 2020; Tetzner et al., 2021). Identifying the origin(s) of the dust and diatoms can indicate air mass pathways as well as the subaerial/surface conditions at the source. The prevalence of open marine and sea ice diatoms at coastal ice rises (Tetzner et al., 2021) would also vary with ice-sheet configuration (i.e., retreated vs advanced). Evidence of circulation changes derived

410 from these imprints can therefore be used to infer fluctuations in ice-sheet grounding-line positions.

Ice core research has so far been largely focused on retrieving records from ice divides in the interior of the ice sheet (Fig. 7) because these sites offer ice-sheet stability (e.g., minimal flow) and low snow accumulation that are suitable for obtaining 
long climate records. However, lower elevation coastal sites, such as coastal ice rises or sub-Antarctic islands at the edge of

415 the ice sheet (Fig. 7), offer greater sensitivity in capturing Holocene changes in coastal climate and ice-sheet processes (e.g., Thomas et al., 2021), including elevation change and ice-sheet readvance (Matsuoka et al., 2015; Neff, 2020). There are, however, very few published records from low elevation sites, with fewer than 20 Antarctic ice core sites from locations below 1500 m elevation (Thomas et al., 2017; Stenni et al., 2017) and none from regions currently experiencing rapid change, such as the Amundsen Sea coast. One reason is that drilling infrastructure expands significantly when collecting

420 such "intermediate depth" ice cores, due to the need for drilling fluid, larger drill equipment, brittle ice precautions (e.g., Neff, 2014), and peripherals needed to handle ice cores on the surface (e.g., Souney et al., 2021). Recovering a complete Holocene ice core from low elevation coastal sites is therefore logistically expensive.

Despite the promise of low elevation sites and coastal domes for detecting Holocene retreat and readvance, there are

425 limitations: (i) The high snow accumulation at coastal sites reduces the number of years that the record contains, (ii) the high concentration of marine aerosols can make dating, particularly the use of volcanic tie-points, challenging (e.g., Winstrup et al., 2019; Moser et al., 2021), (iii) low elevation sites can be susceptible to surface melting (Moser et al., 2021; Thomas et al., 2021), which may compromise the preservation of ice core proxies (Moser et al., 2021), and (iv) complex orography at the ice-sheet margin may limit sites to capturing regional, rather than large-scale, changes in ice-sheet dynamics. These

430 challenges could be addressed in future by collecting multiple cores across a region, utilising a suite of ice core proxies, and prioritising insoluble materials that are less susceptible to melt.

\section{Summary}

There are several complementary approaches that can be used in Antarctica to obtain geological and glaciological records for determining whether, where, and when grounding-line readvance occurred during the Holocene. Of the archives described

435 here, subglacial bedrock and subglacial sediment can provide direct evidence that the AIS was smaller than present during the Holocene, whereas others (marine sediments, radar, records of RSL change, ice cores) have the potential to provide circumstantial evidence consistent with, but not direct proof of, such a hypothesis. The latter situation is notably the case where mechanisms other than retreat and readvance would produce similar features in the records. Such evidence is, nevertheless, useful for corroborating the direct evidence obtained from subglacial sediments and bedrock.

Based on our interpretation of existing datasets, many parts of West Antarctica appear particularly promising for detecting Holocene readvance. The presence of late Holocene gaps in exposure age data arrays in the Weddell Sea and Amundsen Sea embayments, and the outer Ross Sea, point to these as locations where Holocene readvance is likely to have occurred.

Recent studies in the Ross Sea embayment have confirmed that Holocene readvance can be detected (Kingslake et al., 2018),

445 and, furthermore, suggest that its timing can be constrained using direct measurements (Venturelli et al., 2020) and models (Neuhaus et al., 2021). In both the Ross Sea and Weddell Sea, geomorphic evidence of compound grounding zone wedges provides supporting marine evidence that readvance occurred in both regions (Greenwood et al., 2018; Arndt et al., 2017). However, there is apparent inconsistency between subglacial ${ }^{14} \mathrm{C}$ data that provide direct evidence for Holocene grounding line retreat and readvance in the central Ross Sea embayment and exposure age data above the modern ice surface that

450 provide equally direct evidence that Holocene ice sheet thinning and thickening occurred at the embayment margins. Although these lines of evidence could perhaps be reconciled by processes such as, for example, asynchronous forcing of grounding line position or ice thickness, this requires further investigation. In contrast with the Weddell, Amundsen and Ross Sea embayments, there are currently insufficient existing exposure age data or suitable ice cores from most of the East Antarctic coast with which to determine if readvance occurred there or to identify suitable areas for future investigation. That 
455 region is therefore critical for further research if we are to gain a continent-wide picture of late Holocene ice-sheet extent. Finally, low elevation coastal ice rises offer greater sensitivity than interior sites for detecting Holocene grounding-line changes using ice cores, but very few cores from such sites have yet been collected anywhere in Antarctica.

Future research in this area faces considerable logistical challenges because much of the potential evidence for Holocene

460 readvance lies within or beneath the AIS, which is hard to access. Nevertheless, significant progress has been made in the past few years, with successful subglacial bedrock and sediment drilling campaigns undertaken in West Antarctica (Kamb, 2001; Tulaczyk et al., 2014; Boechmann et al., 2021, Priscu et al., 2021). Dating Holocene archives anywhere in Antarctica, particularly those from the past few millennia, is especially difficult due to the low concentrations of accumulated nuclides in bedrock and very small amounts of dateable carbon in subglacial organic material. Furthermore, bringing together

465 glaciological and geological records that have variable resolutions and degrees of uncertainty is not straightforward. Notwithstanding the challenges, determining whether, where, and when the ice sheet grounding line was significantly inboard of its present location during the past few millennia is critical to gaining a mechanistic understanding for readvance behaviour. Obtaining (more) geological records from areas where Holocene deglacial history is currently unknown, or where records are sparse, is essential for this. Further research should focus on improving age constraints and assimilating data

470 from the various direct and indirect archives described here. Research combining multidisciplinary approaches is likely to provide the strongest evidence for or against a smaller-than-present AIS in the Holocene. Only once we understand where readvance occurred and determine its extent can we really begin to understand the mechanisms that drove it.

\section{Author Contributions}

JSJ conceptualised the paper, developed it with RAV and GB, and led the writing process. All authors contributed to writing the manuscript. CSA, GB, BLH, JSJ, PDN, RAV, and JW prepared the figures with input from all co-authors.

\section{Competing Interests}

The authors declare that they have no conflict of interest.

\section{Data availability}

Exposure age data shown in Figure 2 can be downloaded from the ICE-D:ANTARCTICA database at http://antarctica.iced.org.

\section{Acknowledgements}

The authors are grateful for many insightful conversations with the following colleagues that helped formulate the ideas presented here: Robert Ackert (Harvard University), Alex Brisbourne, Claus-Dieter Hillenbrand, Kelly Hogan, Rob Larter, and James Smith (British Antarctic Survey), Chloe Gustafson (Scripps Institute of Oceanography), Ruthie Halberstadt

485 (University of Massachusetts Amherst), Pippa Whitehouse (Durham University), David Pollard (Penn State University), Martin Siegert (Imperial College London). Thank you also to Kate Winter (Northumbria University) who helped prepare Fig. 6. This work is from the Geological History Constraints project, a component of the International Thwaites Glacier Collaboration (ITGC). Support from National Science Foundation (NSF: Grant OPP-1738989) and Natural Environment Research Council (NERC: Grants NE/S006710/1, NE/S00663X/1 and NE/S006753/1). SC is also supported by National 
https://doi.org/10.5194/tc-2021-360

Preprint. Discussion started: 21 December 2021

(c) Author(s) 2021. CC BY 4.0 License.

\section{References}

Aitken, M. J.: Introduction to Optical Dating: The Dating of Quaternary Sediments by the Use of Photon-stimulated Luminescence, Clarendon Press, 282 pp., 1998.

495 Albrecht, T., Winkelmann, R., and Levermann, A.: Glacial-cycle simulations of the Antarctic Ice Sheet with the Parallel Ice Sheet Model (PISM) - Part 1: Boundary conditions and climatic forcing, Cryosphere, 14, 599-632, https://doi.org/10.5194/tc-14-599-2020, 2020a.

Albrecht, T., Winkelmann, R., and Levermann, A.: Glacial-cycle simulations of the Antarctic Ice Sheet with the Parallel Ice

500 Sheet Model (PISM) - Part 2: Parameter ensemble analysis, Cryosphere, 14, 633-656, https://doi.org/10.5194/tc-14-6332020,2020 b.

Allen, C. S., Thomas, E. R., Blagbrough, H., Tetzner, D. R., Warren, R. A., Ludlow, E. C., and Bracegirdle, T. J.: Preliminary Evidence for the Role Played by South Westerly Wind Strength on the Marine Diatom Content of an Antarctic

505 Peninsula Ice Core, (1980-2010), Geosciences, 10, 87, https://doi.org/10.3390/geosciences10030087, 2020.

Andrews, J. T., Domack, E. W., Cunningham, W. L., Leventer, A., Licht, K. J., Jull, A. J. T., DeMaster, D. J., and Jennings, A. E.: Problems and Possible Solutions Concerning Radiocarbon Dating of Surface Marine Sediments, Ross Sea, Antarctica, Quat. Res., 52, 206-216, https://doi.org/10.1006/qres.1999.2047, 1999.

510

Argus, D. F., Peltier, W. R., Drummond, R., and Moore, A. W.: The Antarctica component of postglacial rebound model ICE-6G_C (VM5a) based on GPS positioning, exposure age dating of ice thicknesses, and relative sea level histories, Geophys. J. Int., 198, 537-563, https://doi.org/10.1093/gji/ggu140, 2014.

515 Arndt, J. E., Hillenbrand, C.-D., Grobe, H., Kuhn, G., and Wacker, L.: Evidence for a dynamic grounding line in outer Filchner Trough, Antarctica, until the early Holocene, Geology, 45, 1035-1038, https://doi.org/10.1130/G39398.1, 2017.

Ashmore, D. W., Bingham, R. G., Ross, N., Siegert, M. J., Jordan, T. A., and Mair, D. W. F.: Englacial Architecture and Age-Depth Constraints Across the West Antarctic Ice Sheet, Geophys. Res. Lett., 47, e2019GL086663,

520 https://doi.org/10.1029/2019GL086663, 2020.

Baroni, C. and Hall, B. L.: A new Holocene relative sea-level curve for Terra Nova Bay, Victoria Land, Antarctica, J. Quat Sci., 19, 377-396, https://doi.org/10.1002/jqs.825, 2004.

525 Baroni, C., and Orombelli, G.: Holocene raised beaches at Terra Nova Bay, Victoria Land, Antarctica, Quaternary Res. 36, 157-177, https://doi.org/10.1016/0033-5894(91)90023-X, 1991.

Bentley, M. J., Hodgson, D. A., Sugden, D. E., Roberts, S. J., Smith, J. A., Leng, M. J., and Bryant, C.: Early Holocene retreat of the George VI Ice Shelf, Antarctic Peninsula, Geology, 33, 173, https://doi.org/10.1130/G21203.1, 2005. 
RAISED consortium, Bentley, M. J., Ó Cofaigh, C., Anderson, J. B., Conway, H., Davies, B., Graham, A. G. C., Hillenbrand, C.-D., Hodgson, D. A., Jamieson, S. S. R., Larter, R. D., Mackintosh, A., Smith, J. A., Verleyen, E., Ackert, R. P., Bart, P. J., Berg, S., Brunstein, D., Canals, M., Colhoun, E. A., Crosta, X., Dickens, W. A., Domack, E., Dowdeswell, J. A., Dunbar, R., Ehrmann, W., Evans, J., Favier, V., Fink, D., Fogwill, C. J., Glasser, N. F., Gohl, K., Golledge, N. R.,

535 Goodwin, I., Gore, D. B., Greenwood, S. L., Hall, B. L., Hall, K., Hedding, D. W., Hein, A. S., Hocking, E. P., Jakobsson, M., Johnson, J. S., Jomelli, V., Jones, R. S., Klages, J. P., Kristoffersen, Y., Kuhn, G., Leventer, A., Licht, K., Lilly, K., Lindow, J., Livingstone, S. J., Massé, G., McGlone, M. S., McKay, R. M., Melles, M., Miura, H., Mulvaney, R., Nel, W., Nitsche, F. O., O’Brien, P. E., Post, A. L., Roberts, S. J., Saunders, K. M., Selkirk, P. M., Simms, A. R., Spiegel, C., Stolldorf, T. D., Sugden, D. E., van der Putten, N., van Ommen, T., Verfaillie, D., Vyverman, W., Wagner, B., White, D. A., Witus, A. E., and Zwartz, D.: A community-based geological reconstruction of Antarctic Ice Sheet deglaciation since the Last Glacial Maximum, Quat. Sci. Rev., 100, 1-9, https://doi.org/10.1016/j.quascirev.2014.06.025, 2014.

Bertler, N. A. N., Mayewski, P. A., and Carter, L.: Cold conditions in Antarctica during the Little Ice Age — Implications for abrupt climate change mechanisms, Earth Planet. Sc. Lett., 308, 41-51, https://doi.org/10.1016/j.eps1.2011.05.021, 2011.

Bingham, R. G., Rippin, D. M., Karlsson, N. B., Corr, H. F. J., Ferraccioli, F., Jordan, T. A., Le Brocq, A. M., Rose, K. C., Ross, N., and Siegert, M. J.: Ice-flow structure and ice dynamic changes in the Weddell Sea sector of West Antarctica from radar-imaged internal layering, J. Geophys. Res., 120, 655-670, https://doi.org/10.1002/2014JF003291, 2015.

550 Bodart, J. A., Bingham, R. G., Ashmore, D. W., Karlsson, N. B., Hein, A. S., and Vaughan, D. G.: Age-Depth Stratigraphy of Pine Island Glacier Inferred From Airborne Radar and Ice-Core Chronology, J. Geophys. Res., 126, e2020JF005927, https://doi.org/10.1029/2020JF005927, 2021.

Boeckmann, G. V., Gibson, C. J., Kuhl, T. W., Moravec, E., Johnson, J. A., Meulemans, Z., and Slawny, K.: Adaptation of the Winkie Drill for subglacial bedrock sampling, Ann. Glaciol., 62, 109-117, https://doi.org/10.1017/aog.2020.73, 2021.

Braddock, S., Hall, B.L., Johnson, J.S., Balco, G., Spoth, M., Whitehouse, P.L., Campbell, S., Goehring, B.M., Rood, D.H., and Woodward, J.: Minimal late Holocene ice-mass change inferred from relative sea-level data, Pine Island Bay, Antarctica, Nat. Geosci., in review.

560

Buizert, C., Fudge, T. J., Roberts, W. H. G., Steig, E. J., Sherriff-Tadano, S., Ritz, C., Lefebvre, E., Edwards, J., Kawamura, K., Oyabu, I., Motoyama, H., Kahle, E. C., Jones, T. R., Abe-Ouchi, A., Obase, T., Martin, C., Corr, H., Severinghaus, J. P., Beaudette, R., Epifanio, J. A., Brook, E. J., Martin, K., Chappellaz, J., Aoki, S., Nakazawa, T., Sowers, T. A., Alley, R. B., Ahn, J., Sigl, M., Severi, M., Dunbar, N. W., Svensson, A., Fegyveresi, J. M., He, C., Liu, Z., Zhu, J., Otto-Bliesner, B. L.,

565 Lipenkov, V. Y., Kageyama, M., and Schwander, J.: Antarctic surface temperature and elevation during the Last Glacial Maximum, Science, 372, 1097-1101, https://doi.org/10.1126/science.abd2897, 2021.

Campbell, S., Balco, G., Todd, C., Conway, H., Huybers, K., Simmons, C., and Vermeulen, M.: Radar-detected englacial stratigraphy in the Pensacola Mountains, Antarctica: implications for recent changes in ice flow and accumulation, Ann. 
Clark, P. U., Mitrovica, J. X., Milne, G. A., and Tamisiea, M. E.: Sea-Level Fingerprinting as a Direct Test for the Source of Global Meltwater Pulse IA, Science, 295, 2438-2441, https://doi.org/10.1126/science.1068797, 2002.

575 Conway, H., Hall, B. L., Denton, G. H., Gades, A. M., and Waddington, E. D.: Past and Future Grounding-Line Retreat of the West Antarctic Ice Sheet, Science, 286, 280-283, https://doi.org/10.1126/science.286.5438.280, 1999.

Davis, C. H., Li, Y., McConnell, J. R., Frey, M. M., and Hanna, E.: Snowfall-Driven Growth in East Antarctic Ice Sheet Mitigates Recent Sea-Level Rise, Science, 308, 1898-1901, https://doi.org/10.1126/science.1110662, 2005.

Dixon, D., Mayewski, P. A., Kaspari, S., Sneed, S., and Handley, M.: A 200 year sub-annual record of sulfate in West Antarctica, from 16 ice cores, Ann. Glaciol., 39, 545-556, https://doi.org/10.3189/172756404781814113, 2004.

Dunai, T. J.: Cosmogenic Nuclides: Principles, Concepts and Applications in the Earth Surface Sciences, Cambridge

585 University Press, 199 pp., 2010.

Farquharson, L., Mann, D., Rittenour, T., Groves, P., Grosse, G., and Jones, B.: Alaskan marine transgressions record out-ofphase Arctic Ocean glaciation during the last interglacial, Geology, 46, 783-786, https://doi.org/10.1130/G40345.1, 2018.

590 Fudge, T. J., Markle, B. R., Cuffey, K. M., Buizert, C., Taylor, K. C., Steig, E. J., Waddington, E. D., Conway, H., and Koutnik, M.: Variable relationship between accumulation and temperature in West Antarctica for the past 31,000 years, Geophys. Res. Lett., 43, 3795-3803, https://doi.org/10.1002/2016GL068356, 2016.

Golledge, N. R., Levy, R. H., McKay, R. M., Fogwill, C. J., White, D. A., Graham, A. G. C., Smith, J. A., Hillenbrand, C.595 D., Licht, K. J., Denton, G. H., Ackert, R. P., Maas, S. M., and Hall, B. L.: Glaciology and geological signature of the Last Glacial Maximum Antarctic ice sheet, Quat. Sci. Rev., 78, 225-247, https://doi.org/10.1016/j.quascirev.2013.08.011, 2013.

Gomez, N., Mitrovica, J. X., Tamisiea, M. E., and Clark, P. U.: A new projection of sea level change in response to collapse of marine sectors of the Antarctic Ice Sheet, Geophys. J. Int., 180, 623-634, https://doi.org/10.1111/j.1365-

600 246X.2009.04419.x, 2010.

Gomez, N., Weber, M. E., Clark, P. U., Mitrovica, J. X., and Han, H. K.: Antarctic ice dynamics amplified by Northern Hemisphere sea-level forcing, Nature., 587, 600-604, https://doi.org/10.1038/s41586-020-2916-2, 2020.

605 Goodge, J. W. and Severinghaus, J. P.: Rapid Access Ice Drill: a new tool for exploration of the deep Antarctic ice sheets and subglacial geology, 62, 1049-1064, https://doi.org/10.1017/jog.2016.97, 2016.

Gow, A. J. and Meese, D. A.: Nature of basal debris in the GISP2 and Byrd ice cores and its relevance to bed processes, J. Glaciol., 22, 134-140, https://doi.org/10.3189/1996AoG22-1-134-140, 1996.

610

Greenwood, S. L., Simkins, L. M., Halberstadt, A. R. W., Prothro, L. O., and Anderson, J. B.: Holocene reconfiguration and readvance of the East Antarctic Ice Sheet, Nat. Commun., 9, 3176, https://doi.org/10.1038/s41467-018-05625-3, 2018. 
Greenwood, S. L., Simkins, L. M., Winsborrow, M. C. M., and Bjarnadottir, L. R.: Exceptions to bed-controlled ice sheet

615 flow and retreat from glaciated continental margins worldwide, Sci. Adv., 13, 7(3), https://www.science.org/doi/10.1126/sciadv.abb6291, 2021.

Hall, B. L.: Holocene glacial history of Antarctica and the sub-Antarctic islands, Quaternary Sci. Rev., 28, 2213-2230, https://doi.org/10.1016/j.quascirev.2009.06.011, 2009.

Hall, B. L.: Holocene relative sea-level changes and ice fluctuations in the South Shetland Islands, Global Planet. Change, 74, 15-26, https://doi.org/10.1016/j.gloplacha.2010.07.007, 2010.

Hall, B. L. and Denton, G. H.: New relative sea-level curves for the southern Scott Coast, Antarctica: evidence for Holocene

625 deglaciation of the western Ross Sea, J. Quat. Sci., 14, 641-650, https://doi.org/10.1002/(SICI)10991417(199912)14:7<641::AID-JQS466>3.0.CO;2-B, 1999.

Hall, B. L. and Denton, G. H.: Holocene history of the Wilson Piedmont Glacier along the southern Scott Coast, Antarctica, The Holocene, 12, 619-627, https://doi.org/10.1191/0959683602hl572rp, 2002.

Hall, B. L., Henderson, G. M., Baroni, C., and Kellogg, T. B.: Constant Holocene Southern-Ocean ${ }^{14}$ C reservoir ages and ice-shelf flow rates, Earth Planet. Sc. Lett., 296, 115-123, https://doi.org/10.1016/j.eps1.2010.04.054, 2010.

Hillebrand, T. R., Stone, J. O., Koutnik, M., King, C., Conway, C., Hall, B., Nichols, K., Goehring, B., and Gillespie, M. K.:

635 Holocene thinning and grounding-line retreat of Darwin and Hatherton Glaciers, Antarctica, Cryosphere, 15, 3329-3354, https://doi.org/10.5194/tc-15-3329-2021, 2021.

Holland, D. M., Nicholls, K. W., and Basinski, A.: The southern ocean and its interaction with the Antarctic ice sheet, Science, 367(6484), 1326-1330, http://doi.org/10.1126/science.aaz5491, 2020.

Howat, I. M., Porter, C., Smith, B. E., Noh, M.-J., and Morin, P.: The Reference Elevation Model of Antarctica, Cryosphere, 13, 665-674, https://doi.org/10.5194/tc-13-665-2019, 2019.

John, B. S., and Sugden, D. E.: Raised marine features and phases of glaciation in the South Shetland Islands, British 645 Antarctic Survey Bulletin, 24, 45-111, http://nora.nerc.ac.uk/id/eprint/526463, 1971.

Johnson, J. S., Roberts, S. J., Rood, D. H., Pollard, D., Schaefer, J. M., Whitehouse, P. L., Ireland, L. C., Lamp, J. L., Goehring, B. M., Rand, C., and Smith, J. A.: Deglaciation of Pope Glacier implies widespread early Holocene ice sheet thinning in the Amundsen Sea sector of Antarctica, Earth Planet. Sc. Lett., 548, 116501, https://doi.org/10.1016/j.epsl.2020.116501, 2020. 
Johnson, J. S., Pollard, D., Whitehouse, P. L., Roberts, S. J., Rood, D. H., and Schaefer, J. M.: Comparing Glacial-

Geological Evidence and Model Simulations of Ice Sheet Change since the Last Glacial Period in the Amundsen Sea Sector of Antarctica, J. Geophys. Res.-Earth., 126, https://doi.org/10.1029/2020JF005827, 2021.

655

Jones, R. S., Gudmundsson, G. H., Mackintosh, A. N., McCormack, F. S., and Whitmore, R. J.: Ocean-Driven and

Topography-Controlled Nonlinear Glacier Retreat During the Holocene: Southwestern Ross Sea, Antarctica, Geophys. Res. Lett., 48, e2020GL091454, https://doi.org/10.1029/2020GL091454, 2021.

660 Jouzel, J., Alley, R. B., Cuffey, K. M., Dansgaard, W., Grootes, P., Hoffmann, G., Johnsen, S. J., Koster, R. D., Peel, D., Shuman, C. A., Stievenard, M., Stuiver, M., and White, J.: Validity of the temperature reconstruction from water isotopes in ice cores, J. Geophys. Res.-Oceans, 102, 26471-26487, https://doi.org/10.1029/97JC01283, 1997.

Kamb, B.: Basal Zone of the West Antarctic Ice Streams and its Role in Lubrication of Their Rapid Motion, in: Antarctic

665 Research Series, edited by: Alley, R. B. and Bindschadler, R. A., American Geophysical Union, Washington, D. C., 157199, https://doi.org/10.1029/AR077p0157, 2001.

Kehrl, L., Conway, H., Holschuh, N., Campbell, S., Kurbatov, A. V., and Spaulding, N. E.: Evaluating the Duration and Continuity of Potential Climate Records From the Allan Hills Blue Ice Area, East Antarctica, Geophys. Res. Lett., 45(9), 4096-4104, https://doi.org/10.1029/2018GL077511, 2018.

Kingslake, J., Scherer, R. P., Albrecht, T., Coenen, J., Powell, R. D., Reese, R., Stansell, N. D., Tulaczyk, S., Wearing, M. G., and Whitehouse, P. L.: Extensive retreat and re-advance of the West Antarctic Ice Sheet during the Holocene, Nature, 558, 430-434, https://doi.org/10.1038/s41586-018-0208-x, 2018.

675

Koffman, B. G., Kreutz, K. J., Breton, D. J., Kane, E. J., Winski, D. A., Birkel, S. D., Kurbatov, A. V., and Handley, M. J.: Centennial-scale variability of the Southern Hemisphere westerly wind belt in the eastern Pacific over the past two millennia, Clim. Past, 10, 1125-1144, https://doi.org/10.5194/cp-10-1125-2014, 2014.

680 Kuhl, T., Gibson, C., Johnson, J., Boeckmann, G., Moravec, E., and Slawny, K.: Agile Sub-Ice Geological (ASIG) Drill development and Pirrit Hills field project, Ann. Glaciol., 62, 53-66, https://doi.org/10.1017/aog.2020.59, 2021.

Lambeck, K., Rouby, H., Purcell, A., Sun, Y., and Sambridge, M.: Sea level and global ice volumes from the Last Glacial Maximum to the Holocene, P. Natl. Acad. Sci. USA, 111, 15296-15303, https://doi.org/10.1073/pnas.1411762111, 2014.

685

Larour, E., Seroussi, H., Adhikari, S., Ivins, E., Caron, L., Morlighem, M., and Schlegel, N.: Slowdown in Antarctic mass loss from solid Earth and sea-level feedbacks, Science, 364, eaav7908, https://doi.org/10.1126/science.aav7908, 2019.

Lowry, D. P., Golledge, N. R., Bertler, N. A. N., Jones, R. S., and McKay, R.: Deglacial grounding-line retreat in the Ross

690 Embayment, Antarctica, controlled by ocean and atmosphere forcing, Sci. Adv., 5(8), eaav8754,

https://doi.org/10.1126/sciadv.aav8754, 2019. 
https://doi.org/10.5194/tc-2021-360

Preprint. Discussion started: 21 December 2021

(c) Author(s) 2021. CC BY 4.0 License.

Mann, D. H. and Streveler, G. P.: Post-glacial relative sea level, isostasy, and glacial history in Icy Strait, Southeast Alaska, USA, Quaternary. Res., 69, 201-216, https://doi.org/10.1016/j.yqres.2007.12.005, 2008.

695

Martinerie, P., Raynaud, D., Etheridge, D. M., Barnola, J.-M., and Mazaudier, D.: Physical and climatic parameters which influence the air content in polar ice, Earth Planet. Sc. Lett., 112, 1-13, https://doi.org/10.1016/0012-821X(92)90002-D, 1992.

700 Martinez-Macchiavello, J. C., Tatur, A., Servant-Vildary, S., and Valle, R. D.: Holocene environmental change in a marineestuarine-lacustrine sediment sequence, King George Island, South Shetland Islands, Antarct. Sci., 8, 313-322, https://doi.org/10.1017/S095410209600048X, 1996.

Matsuoka, K., Hindmarsh, R. C. A., Moholdt, G., Bentley, M. J., Pritchard, H. D., Brown, J., Conway, H., Drews, R.,

705 Durand, G., Goldberg, D., Hattermann, T., Kingslake, J., Lenaerts, J. T. M., Martín, C., Mulvaney, R., Nicholls, K. W., Pattyn, F., Ross, N., Scambos, T., and Whitehouse, P. L.: Antarctic ice rises and rumples: Their properties and significance for ice-sheet dynamics and evolution, Earth Science Reviews, 150, 724-745, https://doi.org/10.1016/j.earscirev.2015.09.004, 2015.

710 Mäusbacher, R., Müller, J., and Schmidt, R.: Evolution of postglacial sedimentation in Antarctic lakes (King George Island), Z. Geomorphol., 219-234, https://doi.org/10.1127/zfg/33/1989/219, 1989.

Medley, B. and Thomas, E. R.: Increased snowfall over the Antarctic Ice Sheet mitigated twentieth-century sea-level rise, Nat. Clim. Change, 9, 34-39, https://doi.org/10.1038/s41558-018-0356-x, 2019.

715

Mills, S. C., Brocq, A. M. L., Winter, K., Smith, M., Hillier, J., Ardakova, E., Boston, C. M., Sugden, D., and Woodward, J.: Testing and application of a model for snow redistribution (Snow_Blow) in the Ellsworth Mountains, Antarctica, J. Glaciol., 65, 957-970, https://doi.org/10.1017/jog.2019.70, 2019.

720 Moser, D. E., Jackson, S., Kjær, H. A., Markle, B., Ngoumtsa, E., Pedro, J. B., Segato, D., Spolaor, A., Tetzner, D., Vallelonga, P., and Thomas, E. R.: An Age Scale for the First Shallow (Sub-)Antarctic Ice Core from Young Island, Northwest Ross Sea, Geosci., 11, 368, https://doi.org/10.3390/geosciences11090368, 2021.

Motyka, R. J.: Little Ice Age subsidence and post Little Ice Age uplift at Juneau, Alaska, inferred from dendrochronology

725 and geomorphology, Quaternary Res., 59, 300-309, https://doi.org/10.1016/S0033-5894(03)00032-2, 2003.

Neff, P. D.: A review of the brittle ice zone in polar ice cores. Ann. Glaciol., 55(68), 72-82,

https://doi.org/10.3189/2014AoG68A023, 2014.

730 Neff, P.: Amundsen Sea Coastal Ice Rises, Oceanography, 3(2), 88-89, https://doi.org/10.5670/oceanog.2020.215, 2020. 

Antarctica, inferred from radar-detected internal layers, J. Glaciol., 46, 75-87, https://doi.org/10.3189/172756500781833449, 2000.

Neuhaus, S. U., Tulaczyk, S. M., Stansell, N. D., Coenen, J. J., Scherer, R. P., Mikucki, J. A., and Powell, R. D.: Did Holocene climate changes drive West Antarctic grounding line retreat and readvance?, Cryosphere, 15, 4655-4673, https://doi.org/10.5194/tc-15-4655-2021, 2021.

740 Nichols, K. A.: The Glacial History of the Weddell Sea Embayment, Antarctica, Ph.D., Tulane University School of Science and Engineering, United States -- Louisiana, 149 pp., 2020.

Peltier, W. R., Argus, D. F., and Drummond, R.: Space geodesy constrains ice age terminal deglaciation: The global ICE6G_C (VM5a) model, J. Geophys. Res.-Sol. Ea., 120, 450-487, https://doi.org/10.1002/2014JB011176, 2015.

Pollard, D. and DeConto, R. M.: Description of a hybrid ice sheet-shelf model, and application to Antarctica, Geosci. Model Dev., 5, 1273-1295, https://doi.org/10.5194/gmd-5-1273-2012, 2012.

Priscu, J. C., Kalin, J., Winans, J., Campbell, T., Siegfried, M. R., Skidmore, M., Dore, J. E., Leventer, A., Harwood, D. M.,

750 Duling, D., Zook, R., Burnett, J., Gibson, D., Krula, E., Mironov, A., McManis, J., Roberts, G., Rosenheim, B. E., Christner, B. C., Kasic, K., Fricker, H. A., Lyons, W. B., Barker, J., Bowling, M., Collins, B., Davis, C., Gagnon, A., Gardner, C.,

Gustafson, C., Kim, O.-S., Li, W., Michaud, A., Patterson, M. O., Tranter, M., Venturelli, R., Vick-Majors, T., Elsworth, C., and The SALSA Science Team: Scientific access into Mercer Subglacial Lake: scientific objectives, drilling operations and initial observations, Ann. Glaciol., 1-13, https://doi.org/10.1017/aog.2021.10, 2021.

755

Pudsey, C. J., Evans, J., Domack, E. W., Morris, P., and Valle, R. A. D.: Bathymetry and acoustic facies beneath the former Larsen-A and Prince Gustav ice shelves, north-west Weddell Sea, Antarct. Sci., 13, 312-322, https://doi.org/10.1017/S095410200100044X, 2001.

760 Raymond, C. F.: Deformation in the Vicinity of Ice Divides, J. Glaciol., 29, 357-373, https://doi.org/10.3189/S0022143000030288, 1983.

Roberts, S. J., Hodgson, D. A., Sterken, M., Whitehouse, P. L., Verleyen, E., Vyverman, W., Sabbe, K., Balbo, A., Bentley, M. J., and Moreton, S. G.: Geological constraints on glacio-isostatic adjustment models of relative sea-level change during

765 deglaciation of Prince Gustav Channel, Antarctic Peninsula, Quaternary Sci. Rev., 30, 3603-3617, https://doi.org/10.1016/j.quascirev.2011.09.009, 2011.

Rosenheim, B. E., Day, M. B., Domack, E., Schrum, H., Benthien, A., and Hayes, J. M.: Antarctic sediment chronology by programmed-temperature pyrolysis: Methodology and data treatment, Geochem. Geophys. Geosyst., 9(4), Q04005, https://doi.org/10.1029/2007GC001816, 2008. 
Sackett, W. M.: Organic carbon in sediments underlying the Ross Ice Shelf, Org. Geochem., 9, 135-137, https://doi.org/10.1016/0146-6380(86)90103-8, 1986.

775 Scambos, T. A., Hulbe, C., Fahnestock, M., and Bohlander, J.: The link between climate warming and break-up of ice shelves in the Antarctic Peninsula, J. Glaciol., 46, 516-530, https://doi.org/10.3189/172756500781833043, 2000.

Schroeder, D. M., Dowdeswell, J. A., Siegert, M. J., Bingham, R. G., Chu, W., MacKie, E. J., Siegfried, M. R., Vega, K. I., Emmons, J. R., and Winstein, K.: Multidecadal observations of the Antarctic ice sheet from restored analog radar records, P.

780 Natl. Acad. Sci. USA, 116, 18867-18873, https://doi.org/10.1073/pnas.1821646116, 2019.

Siegert, M., Ross, N., Corr, H., Kingslake, J., and Hindmarsh, R.: Late Holocene ice-flow reconfiguration in the Weddell Sea sector of West Antarctica, Quaternary Sci. Rev., 78, 98-107, https://doi.org/10.1016/j.quascirev.2013.08.003, 2013.

785 Simkins, L. M., Simms, A. R., and DeWitt, R.: Relative sea-level history of Marguerite Bay, Antarctic Peninsula derived from optically stimulated luminescence-dated beach cobbles, Quaternary Sci. Rev., 77, 141-155, https://doi.org/10.1016/j.quascirev.2013.07.027, 2013.

Simms, A. R., DeWitt, R., Kouremenos, P., and Drewry, A. M.: A new approach to reconstructing sea levels in Antarctica using optically stimulated luminescence of cobble surfaces, Quaternary Geochronol., 6, 50-60, https://doi.org/10.1016/j.quageo.2010.06.004, 2011.

Simms, A. R., Ivins, E. R., DeWitt, R., Kouremenos, P., and Simkins, L. M.: Timing of the most recent Neoglacial advance and retreat in the South Shetland Islands, Antarctic Peninsula: insights from raised beaches and Holocene uplift rates,

795 Quaternary Sci. Rev., 47, 41-55, https://doi.org/10.1016/j.quascirev.2012.05.013, 2012.

Simms, A. R., Bentley, M. J., Simkins, L. M., Zurbuchen, J., Reynolds, L. C., DeWitt, R., and Thomas, E. R.: Evidence for a "Little Ice Age" glacial advance within the Antarctic Peninsula - Examples from glacially-overrun raised beaches, Quaternary Sci. Rev., 271, 107195, https://doi.org/10.1016/j.quascirev.2021.107195, 2021.

Smith, J. A., Bentley, M. J., Hodgson, D. A., Roberts, S. J., Leng, M. J., Lloyd, J. M., Barrett, M. S., Bryant, C., and Sugden, D. E.: Oceanic and atmospheric forcing of early Holocene ice shelf retreat, George VI Ice Shelf, Antarctica Peninsula, Quaternary Sci. Rev., 26, 500-516, https://doi.org/10.1016/j.quascirev.2006.05.006, 2007.

805 Smith, J. A., Graham, A. G. C., Post, A. L., Hillenbrand, C.-D., Bart, P. J., and Powell, R. D.: The marine geological imprint of Antarctic ice shelves, Nat. Commun., 10, 5635, https://doi.org/10.1038/s41467-019-13496-5, 2019.

Smith, J. A., Hillenbrand, C.-D., Subt, C., Rosenheim, B. E., Frederichs, T., Ehrmann, W., Andersen, T. J., Wacker, L., Makinson, K., Anker, P., Venables, E. J., and Nicholls, K. W.: History of the Larsen C Ice Shelf reconstructed from sub-ice 810 shelf and offshore sediments, Geology, 49, 978-982, https://doi.org/10.1130/G48503.1, 2021. 
Souney, J. M., Twickler, M. S., Aydin, M., Steig, E. J., Fudge, T. J., Street, L. V., Nicewonger, M. R., Kahle, E. C., Johnson, J. A., Kuhl, T. W., Casey, K. A., Fegyveresi, J. M., Nunn, R. M., and Hargreaves, G. M.: Core handling, transportation and processing for the South Pole ice core (SPICEcore) project, Ann. Glaciol., 62, 118-130, https://doi.org/10.1017/aog.2020.80, 8152021.

Spector, P., Stone, J., Pollard, D., Hillebrand, T., Lewis, C., and Gombiner, J.: West Antarctic sites for subglacial drilling to test for past ice-sheet collapse, Cryosphere, 12, 2741-2757, https://doi.org/10.5194/tc-12-2741-2018, 2018.

820 Spector, P., Stone, J., and Goehring, B.: Thickness of the divide and flank of the West Antarctic Ice Sheet through the last deglaciation, 13, 3061-3075, Cryosphere, https://doi.org/10.5194/tc-13-3061-2019, 2019.

Steig, E. J., Morse, D. L., Waddington, E. D., Stuiver, M., Grootes, P. M., Mayewski, P. A., Twickler, M. S., and Whitlow, S. I.: Wisconsinan and holocene climate history from an ice core at taylor dome, western ross embayment, antarctica, Geogr.

Ann. A., 82, 213-235, https://doi.org/10.1111/j.0435-3676.2000.00122.x, 2000.

Stenni, B., Curran, M. A. J., Abram, N. J., Orsi, A., Goursaud, S., Masson-Delmotte, V., Neukom, R., Goosse, H., Divine, D., van Ommen, T., Steig, E. J., Dixon, D. A., Thomas, E. R., Bertler, N. A. N., Isaksson, E., Ekaykin, A., Werner, M., and Frezzotti, M.: Antarctic climate variability on regional and continental scales over the last 2000 years, Clim. Past., 13, 16091634, https://doi.org/10.5194/cp-13-1609-2017, 2017.

Stone, J. O., Balco, G. A., Sugden, D. E., Caffee, M. W., Sass, L. C., Cowdery, S. G., and Siddoway, C.: Holocene Deglaciation of Marie Byrd Land, West Antarctica, Science, 299, 99-102, https://doi.org/10.1126/science.1077998, 2003.

835 Tetzner, D. R., Thomas, E. R., and Allen, C. S.: Marine diatoms in ice cores from the Antarctic Peninsula and Ellsworth Land, Antarctica -species diversity and regional variability, The Cryosphere Discuss. [preprint], https://doi.org/10.5194/tc2021-160, in review, 2021.

Thomas, E. R., Hosking, J. S., Tuckwell, R. R., Warren, R. A., and Ludlow, E. C.: Twentieth century increase in snowfall in coastal West Antarctica, Geophys. Res. Lett., 42, 9387-9393, https://doi.org/10.1002/2015GL065750, 2015.

Thomas, E. R., van Wessem, J. M., Roberts, J., Isaksson, E., Schlosser, E., Fudge, T. J., Vallelonga, P., Medley, B., Lenaerts, J., Bertler, N., van den Broeke, M. R., Dixon, D. A., Frezzotti, M., Stenni, B., Curran, M., and Ekaykin, A. A.: Regional Antarctic snow accumulation over the past 1000 years, Clim. Past, 13, 1491-1513, https://doi.org/10.5194/cp-13845 1491-2017, 2017.

Thomas, E. R., Gacitúa, G., Pedro, J. B., Faith King, A. C., Markle, B., Potocki, M., and Moser, D. E.: Physical properties of shallow ice cores from Antarctic and sub-Antarctic islands, Cryosphere, 15, 1173-1186, https://doi.org/10.5194/tc-15-11732021, 2021.

850

Tulaczyk, S., Mikucki, J. A., Siegfried, M. R., Priscu, J. C., Barcheck, C. G., Beem, L. H., Behar, A., Burnett, J., Christner, B. C., Fisher, A. T., Fricker, H. A., Mankoff, K. D., Powell, R. D., Rack, F., Sampson, D., Scherer, R. P., Schwartz, S. Y., 
and The Wissard Science Team: WISSARD at Subglacial Lake Whillans, West Antarctica: scientific operations and initial observations, Ann. Glaciol., 55, 51-58, https://doi.org/10.3189/2014AoG65A009, 2014.

855

Vaughan, D. G., Corr, H. F. J., Doake, C. S. M., and Waddington, E. D.: Distortion of isochronous layers in ice revealed by ground-penetrating radar, Nature, 398, 323-326, https://doi.org/10.1038/18653, 1999.

Venturelli, R. A.: Investigating the Recent History of a Changing Planet with Innovative Isotopic Techniques and New

Geologic Archives, University of South Florida, 2021.

Venturelli, R. A., Siegfried, M. R., Roush, K. A., Li, W., Burnett, J., Zook, R., Fricker, H. A., Priscu, J. C., Leventer, A., and Rosenheim, B. E.: Mid-Holocene Grounding Line Retreat and Readvance at Whillans Ice Stream, West Antarctica, Geophys. Res. Lett., 47, https://doi.org/10.1029/2020GL088476, 2020.

865

Verleyen, E., Hodgson, D. A., Milne, G. A., Sabbe, K., and Vyverman, W.: Relative sea-level history from the Lambert Glacier region, East Antarctica, and its relation to deglaciation and Holocene glacier readvance, Quaternary Res., 63, 45-52, https://doi.org/10.1016/j.yqres.2004.09.005, 2005.

870 Verleyen, E., Tavernier, I., Hodgson, D. A., Whitehouse, P. L., Kudoh, S., Imura, S., Heirman, K., Bentley, M. J., Roberts, S. J., De Batist, M., Sabbe, K., and Vyverman, W.: Ice sheet retreat and glacio-isostatic adjustment in Lützow-Holm Bay, East Antarctica, Quaternary Sci. Rev., 169, 85-98, https://doi.org/10.1016/j.quascirev.2017.06.003, 2017.

Watcham, E. P., Bentley, M. J., Hodgson, D. A., Roberts, S. J., Fretwell, P. T., Lloyd, J. M., Larter, R. D., Whitehouse, P. 875 L., Leng, M. J., Monien, P., and Moreton, S. G.: A new Holocene relative sea level curve for the South Shetland Islands, Antarctica, Quaternary Sci. Rev., 30, 3152-3170, https://doi.org/10.1016/j.quascirev.2011.07.021, 2011.

Werner, M., Jouzel, J., Masson-Delmotte, V., and Lohmann, G.: Reconciling glacial Antarctic water stable isotopes with ice sheet topography and the isotopic paleothermometer, Nat. Commun., 9, 3537, https://doi.org/10.1038/s41467-018-05430-y, 2018.

Whitehouse, P. L., Bentley, M. J., Milne, G. A., King, M. A., and Thomas, I. D.: A new glacial isostatic adjustment model for Antarctica: calibrated and tested using observations of relative sea-level change and present-day uplift rates, Geophysical J. Int., 190, 1464-1482, https://doi.org/10.1111/j.1365-246X.2012.05557.x, 2012.

Winstrup, M., Vallelonga, P., Kjær, H. A., Fudge, T. J., Lee, J. E., Riis, M. H., Edwards, R., Bertler, N. A. N., Blunier, T., Brook, E. J., Buizert, C., Ciobanu, G., Conway, H., Dahl-Jensen, D., Ellis, A., Emanuelsson, B. D., Hindmarsh, R. C. A., Keller, E. D., Kurbatov, A. V., Mayewski, P. A., Neff, P. D., Pyne, R. L., Simonsen, M. F., Svensson, A., Tuohy, A., Waddington, E. D., and Wheatley, S.: A 2700-year annual timescale and accumulation history for an ice core from Roosevelt Island, West Antarctica, Clim. Past, 15, 751-779, https://doi.org/10.5194/cp-15-751-2019, 2019. 
https://doi.org/10.5194/tc-2021-360

Preprint. Discussion started: 21 December 2021

(c) Author(s) 2021. CC BY 4.0 License.

(c) (i)

Winter, K., Woodward, J., Dunning, S. A., Turney, C. S. M., Fogwill, C. J., Hein, A. S., Golledge, N. R., Bingham, R. G., Marrero, S. M., Sugden, D. E., and Ross, N.: Assessing the continuity of the blue ice climate record at Patriot Hills, Horseshoe Valley, West Antarctica, Geophys. Res. Lett., 43, 2019-2026, https://doi.org/10.1002/2015GL066476, 2016.

895

Winter, A., Steinhage, D., Creyts, T. T., Kleiner, T., and Eisen, O.: Age stratigraphy in the East Antarctic Ice Sheet inferred from radio-echo sounding horizons, Earth Syst. Sci. Data, 11, 1069-1081, https://doi.org/10.5194/essd-11-1069-2019, 2019.

Yokoyama, Y., Anderson, J. B., Yamane, M., Simkins, L. M., Miyairi, Y., Yamazaki, T., Koizumi, M., Suga, H., Kusahara,

900 K., Prothro, L., Hasumi, H., Southon, J. R., and Ohkouchi, N.: Widespread collapse of the Ross Ice Shelf during the late Holocene, P. Natl. Acad. Sci. USA, 113, 2354-2359, https://doi.org/10.1073/pnas.1516908113, 2016.

Zwartz, D., Bird, M., Stone, J., and Lambeck, K.: Holocene sea-level change and ice-sheet history in the Vestfold Hills, East Antarctica, Earth Planet. Sc. Lett., 155, 131-145, https://doi.org/10.1016/S0012-821X(97)00204-5, 1998. 